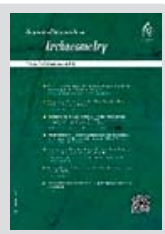

Original Paper

\title{
Lustre Production in Kerman; Typology and Elemental analysis of Lustrewares of Exhibition and Pottery Bank of Arg-e Bam
}

\author{
Neda Kameshki ${ }^{1}$, Saeed Amirhajloo ${ }^{2 *}$, Davoud Agha-Aligol ${ }^{3}$, Meisam Shahsavari4, \\ Leiyla Fazel ${ }^{5}$ \\ 1. M.A in Archaeology, the Employee of the Bam world heritage site, Bam, IRAN \\ 2. Assistant Professor, Department of Archeology, Tarbiat Modares University, Tehran, IRAN \\ 3. Physics and Accelerators Research School, Nuclear Science and Technology Research Institute, \\ Tehran, IRAN \\ 4. Assistant Professor, Department of Archaeology, University of Jiroft, IRAN \\ 5. PhD student in Archaeology, Bu-Ali Sina University and the Employee of the Bam World Heritage \\ Site, Bam, IRAN
}

Received: 19/04/2021

Accepted: 21/08/2021

\begin{abstract}
Significant evidence of the lustre has been discovered during the excavation and restoration of the historical Arg-e Bam. 24 samples of these lustres are kept in the pottery bank and Exhibition of the Arg Bam. There are the following questions about them: what are the characteristic features of the lustrewares in the pottery bank and exhibition of the Arg-e Bam? Where is the production center of these lustrewares based on laboratory results? What local pottery traditions have existed in the production of lustreware in Kerman? After classification and typology of the lustrewares, 10 pieces have been chosen as the samples to perform elemental analysis of the body and glaze by the microPIXE method. The results of the elemental analysis of the paste and glaze indicated that these samples are of local origin and their raw materials are supplied from mines in Bam, Jiroft, or Kerman and produced in the same area. Therefore, the variety that can be seen in the color, pattern, and paste of these lustrewares is not due to their production in several centers in Iran, but due to production in different periods from the early to the late Islamic centuries in several local workshops in Kerman, Jiroft, or Bam.
\end{abstract}

Keywords: Elemental analysis of pottery, Micro-PIXE, Arg-e Bam, Lustreware, Luster Glaze.

\section{Introduction}

The studies on the origin of lustre found in Jiroft and Qal'eh Dokhtar of Kerman shows that Kerman region was one of the centers of lustre production in the middle Islamic centuries. Significant samples of lustre ceramics and tiles have been obtained from Arg-e Bam, which were considered in this article. The purpose is to classify the lustrewares of pottery bank and exhibition of the Arg-e Bam in order to explain the stylistic and chronological features, the origin of lustrewares based on laboratory analysis, and to explain the characteristics of local products. The study of these samples clarifies the diversity and distribution of lustrewares in the Jiroft-BamKerman zone.

*Corresponding Author: s.amirhajloo@modares.ac.ir

Copyright $($ 2021, the Authors / This open-access article is published under the terms of the Creative Commons Attribution-NonCommercial 4.0 International License which permits Share (copy and redistribute the material in any medium or format) and Adapt (remix, transform, and build upon the material) under the Attribution-NonCommercial .terms 


\section{Materials and Methods}

Arg-e Bam is located in the northeast of the modern city of Bam, in the southeast of Kerman province (Figure 1). Numerous archaeological data have been discovered in the archeological and restoration activities of Arg-e Bam, including pieces of lustrewares. Currently, 24 pieces of these lustres are kept in the Pottery Bank and the Exhibition of the Arg-e Bam (Figure 2).

These lustrewares includes plates, bowls, cups, and closed-mouth containers, and based on the paste, they include clay, stone-paste, and porcelain. Depending on the color of the lustre layer, there are different colors of pale gold, olive gold, reddish gold or jujube, and brownish gold in Arg-e Bam samples (Figure 3). Also, based on the pattern, the studied lustrewares are divided into the monumental and miniature style. Various linear and doted motifs, linear and radial branching from the center of the vessel, realistic plant shapes, Khitai flowers, arabesque and pseudo-arabesque forms, Toranj, inscriptions of Naskh and Ta'liq or pseudo-inscriptions, geometric patterns, Mongolian faces, birds such as ducks and animals such as horses can be seen on the lustrewares of Arg-e Bam (Figure 4). Most of them are belong to the early and middle Islamic centuries, and one sample belongs to the late Islamic centuries (probably Safavid) (Table 1).

In this study, a proton beam with an energy of $2.2 \mathrm{MeV}$ with an intensity of about $50 \mathrm{pA}$ was used for micro-PIXE analysis, which is produced by $3 \mathrm{MV}$ Van de graaff accelerator at the Nuclear Science and Technology Research Institute of Iran in Tehran. The diameter of the proton beam in these experiments is set to less than 10 microns. The characteristic X-rays were detected using a $\mathrm{Si}$ (Li) detector at an angle of $135^{\circ}$ relative to the incident proton beam direction with an energy resolution of $150 \mathrm{eV}$.

\section{Results}

The results of paste analysis by micro-PIXE method indicate the presence of $\mathrm{Na} 2 \mathrm{O}, \mathrm{MgO}, \mathrm{Al} 2 \mathrm{O} 3$, $\mathrm{SiO} 2, \mathrm{P} 2 \mathrm{O} 5, \mathrm{SO} 3, \mathrm{Cl}, \mathrm{K} 2 \mathrm{O}, \mathrm{CaO}$, TiO2, $\mathrm{Cr} 2 \mathrm{O} 3, \mathrm{MnO}, \mathrm{Fe} 2 \mathrm{O} 3, \mathrm{SrO}, \mathrm{PbO}$ in the paste of lustrewares of Arg-e Bam (Table 2; Figures 6 to 8).

Also, based on the test results of the base glaze and lustre layer, in addition to sodium, magnesium, aluminum, silica, phosphorus, sulfur, chlorine, potassium, calcium, titanium, manganese, chromium, iron, strontium, and lead, there is also copper, zinc, cobalt, silver, and tin (Table 3).

\section{Discussion}

Micro-PIXE analysis of the samples indicates the presence of magnesium in the elemental composition of these lustrewares, as in the samples of Qal'eh Dokhtar in Kerman [10]. While the presence of magnesium in the lustre glazes in the samples of Kashan, Rey, Takht-e-Soliman, Gorgan, and Alamut has not been reported so far and the only exception is the lustrewares of the underground complex of Tappeh Ghaleh in Khomein [36]. But magnesium is less present in Khomein's lustrewares. As this element in Khomein samples, on average, $1.22 \%$ by weight of glaze and in Arg-e Bam samples, on average, 2.12\%.

Based on geological studies, magnesium mineral has been identified in Kerman province, especially Ashin valley around Jiroft. The presence of magnesium in the body of the lustrewares of Qal'eh Dokhtar in Kerman indicates the dolomitic origin and extraction from metamorphic areas, and such a situation exists in the Kerman province [37]. Previous studies showed that Jiroft and Kerman region were producing centers of lustreware $[6,8,9]$. Lustre production in these regions in the neighborhood of Bam, is important in explaining the local production of lustrewares in Arg-e Bam.

Also, the comparison of the compounds in the paste and lustre layer in Arg-e Bam samples with other regions of Iran including Kashan, Susa, Gorgan, Takht-e Soleiman, and Reyy show many differences, while compared to Qal'eh Dokhtar samples, There is the most similarity (Tables 4 and 5). Elements such as phosphorus, sodium, and sulfur are present in the glaze of Arg-e Bam and Qal'eh Dokhtar in Kerman. While samples from other regions of Iran do not have these elements. Therefore, the difference between the raw materials of Arg-e Bam samples and Kashan, Reyy, and Takht-e-Soliman samples can indicate a different production formulation.

Also, the local characteristics of the lustrewares of Arg-e Bam are: 
A) Various colors of lustre glaze,

B) Various patterns; including monumental and miniature style,

C) Existence of abstract motifs, realistic and khitai plants, arabesque and pseudo-arabesque, Toranj, animal and human, geometric, inscriptions of Naskh and Ta'liq or pseudo-inscriptions, and combined motifs.

\section{Conclusion}

The results showed that the lustrewares of the Arg-e Bam have some magnesium and the presence of this element in the metamorphic region of Kerman, Jiroft, and Bam is definite. While in the lustrewares of Kashan, Reyy, Gorgan, and Takht-e-Soliman as important centers of lustre production, magnesium has not been reported. In addition, there are elements such as phosphorus, sodium, and sulfur in the glaze composition of Arg-e Bam and Qal'eh Dokhtar in Kerman. While samples from other regions of Iran do not have these elements. Therefore, it seems that the origin of the lustres of Arg-e Bam is different from the origin of the lustres of Kashan, Reyy, Takht-eSoliman, and Gorgan. Probably the raw materials of Arg-e Bam samples were supplied from mines in Bam, Jiroft, or Kerman, especially Ashin Valley in Jiroft. Accordingly, the variety that can be seen in the color, pattern, and paste of the Arg-e Bam lustrewares have not been due to their production in several centers in different parts of Iran. Rather, it has been due to production in different periods from the early to the late Islamic centuries, in several local workshops in Kerman, Bam, and Jiroft. 


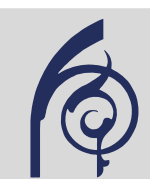

;

DOI: $\underline{10.29252 / \mathrm{jra} \cdot 7.1 .81}$

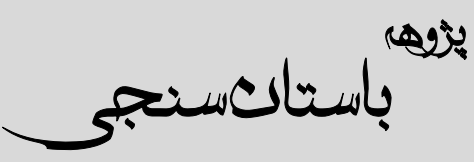

URL: http://jra-tabriziau.ir/

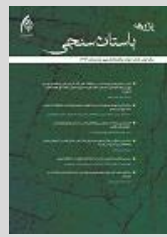

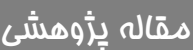

\section{صنعت توليد سفال زرينفام در ناحيه كرمان؛ تَونهشناسى

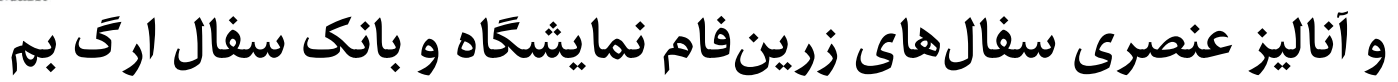

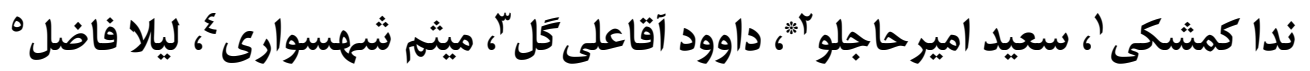

ا ـ كارشناسارشد باستانشناسى، يايخاه ميراث جهانى به، ايران

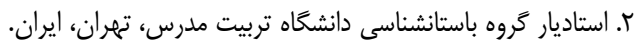

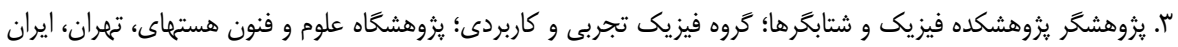

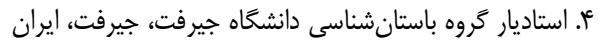

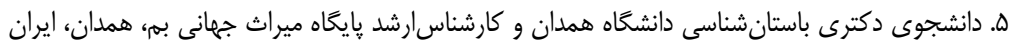

سفال زرينفام از جمله مواد فرهنگى فاخر دوران اسلامى بوده و توليد آن در ايران به دليل يِيجيدگى فنـاورى، در انحصـار مراكـز

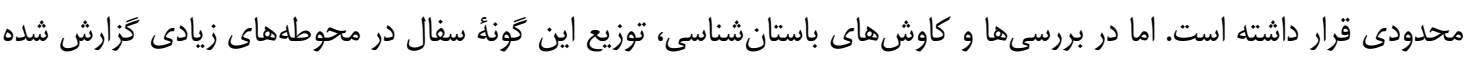

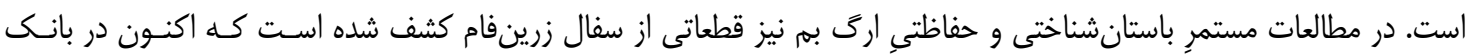

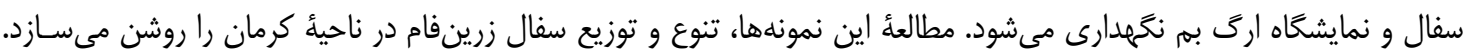

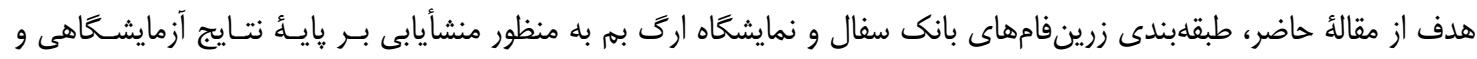

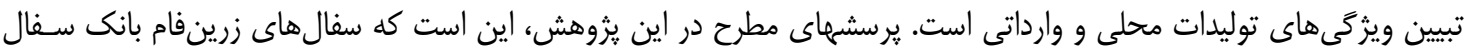

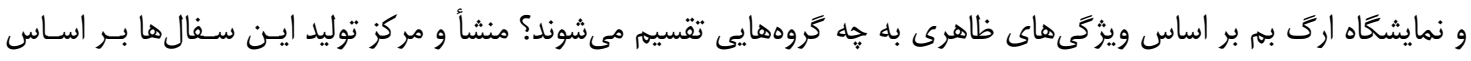

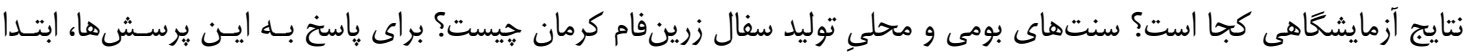

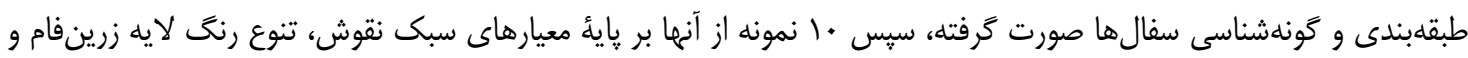

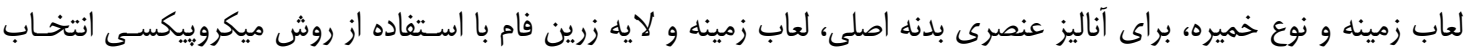

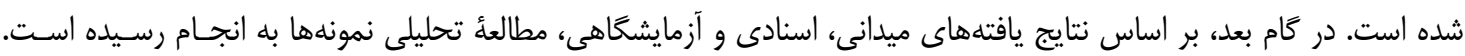

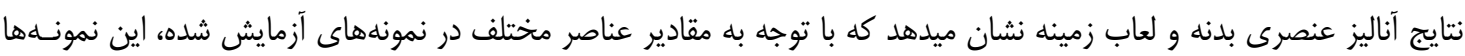

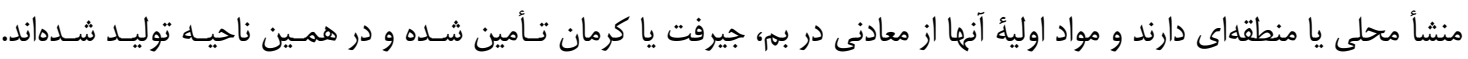

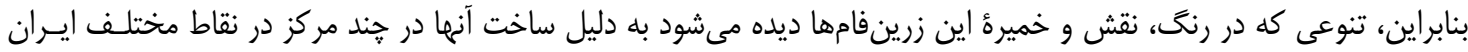

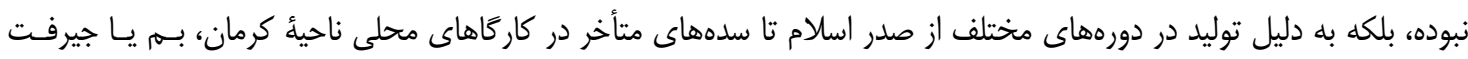

$$
\text { بوده است. }
$$

$$
\text { وازَّان كليدى: آناليز عنصرى سفال، ميكروييكسى، ارگ قديم به، سفال زرينفام، لعاب زرينفام }
$$

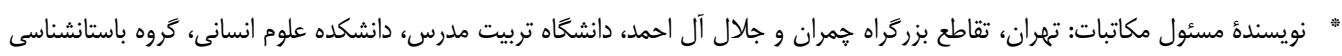
s.amirhajloo@modares.ac.ir يست الكترونيكى

C) حق نشر متعلق به نويسنده(كان) است و نويسنده تحت مجوز Creative Commons Attribution License به مجله اجازه مىدهد مقاله جاب شده را با ديخران به اشتراك بحذارد منوط بر اينكه حقوق مؤلف اثر حفظ و به انتشار اوليه مقاله در اين مجله اشاره شود. 


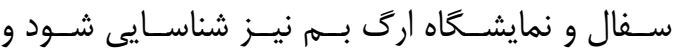

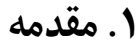
ويزگى هاى توليدات محلى زرينفام در نـواحى كرمـان

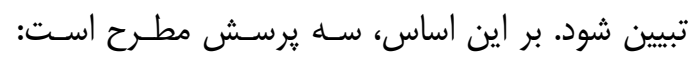
نخست، سفال هاى زرينفام بانـك سـفال و نمايشـاه

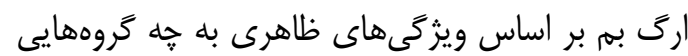
تقسيم مىشوند؟ دوم، منشأ و مركز توليد اين سـفالها

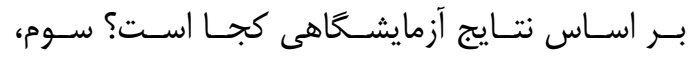

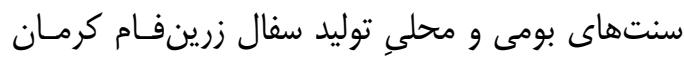

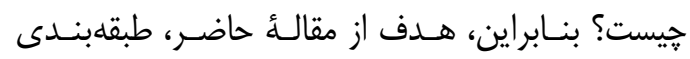

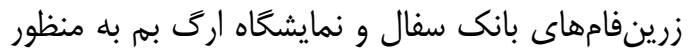

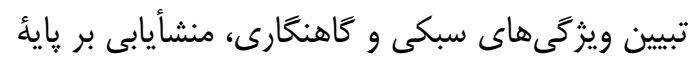

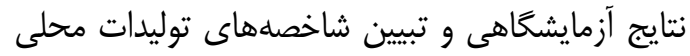

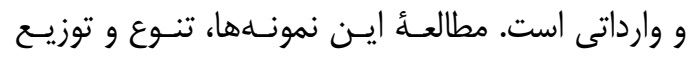

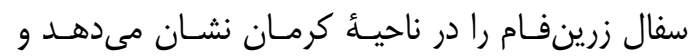

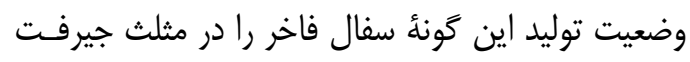

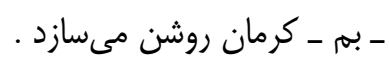

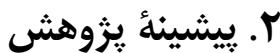

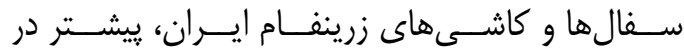

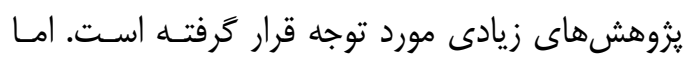

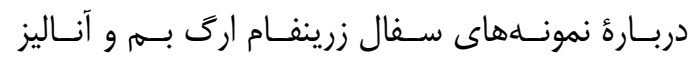
عنصرى بدنه و لعاب آنها تاكنون هيج يزوهشى زئه منتشـر

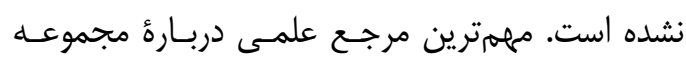

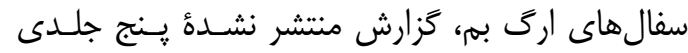

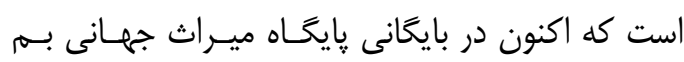

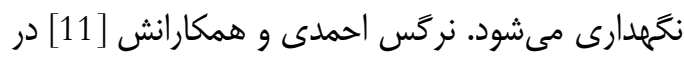

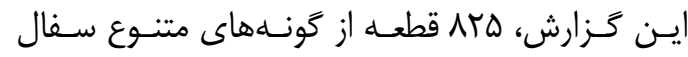

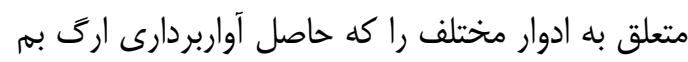

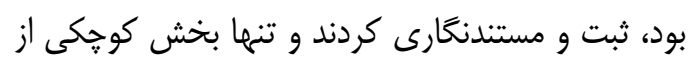

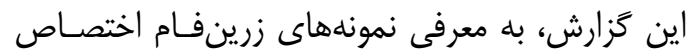

با اين همه، يزوهشهاى سـفال و كاشى زرينفـام در

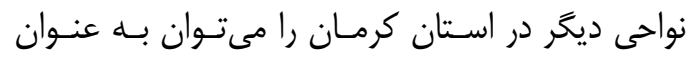

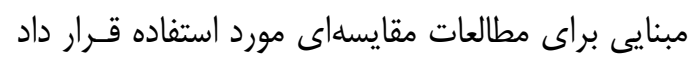

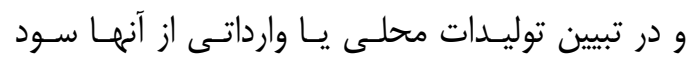
جسـت. حميــده جوبـــ [9] در مقالـهاى بــا عنـوان

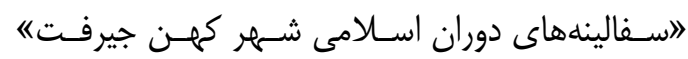

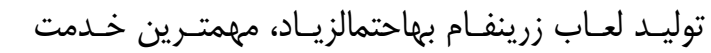

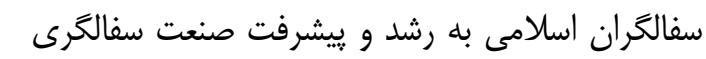
در جهان بوده است. جلوهُ درخشان و براقي لعاب زرينفام

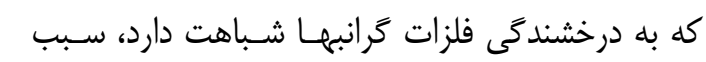

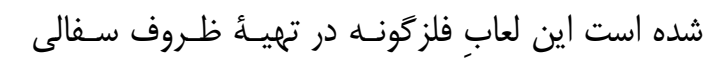

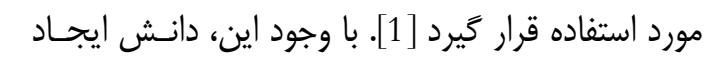

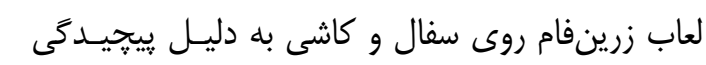

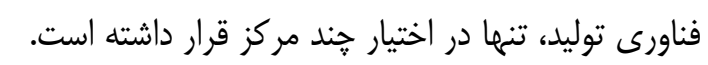

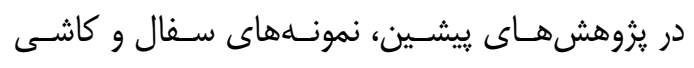

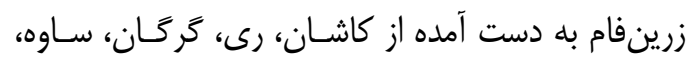

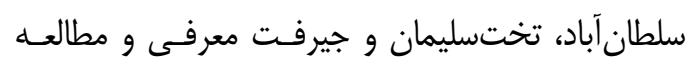

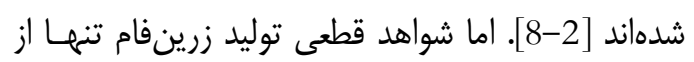

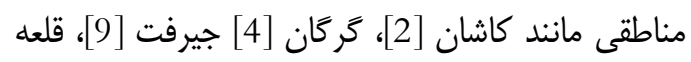

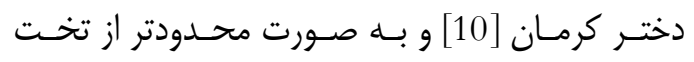
سليمان [8] شناسايى شده است ـ داست

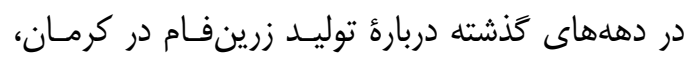

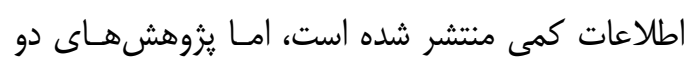

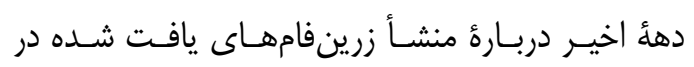
جيرفت و كرمان نشان مىدهد كه ناحيـأ كرمـان نيـز

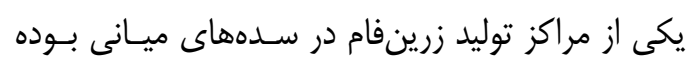

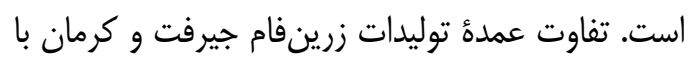

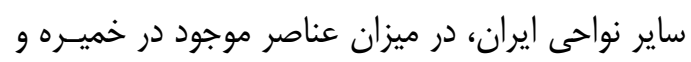
لعاب و همجنين، وجود منيزيم در تركيبات اين نمان نمونها

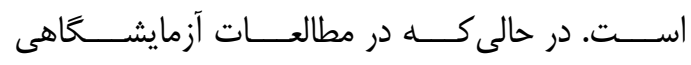

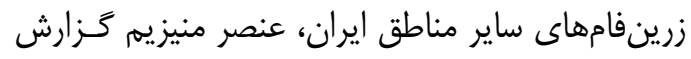
نشده است [10]. در فعاليتهاى باستانشناختى، مرمتى و حفاظتى پايايخاه

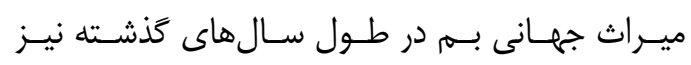

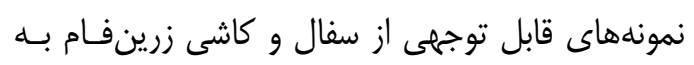

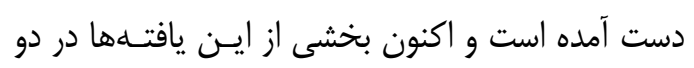

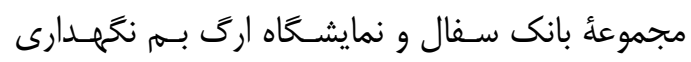

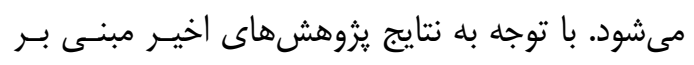

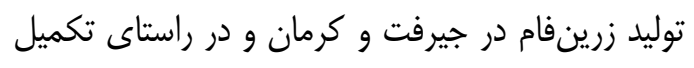

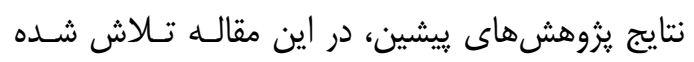

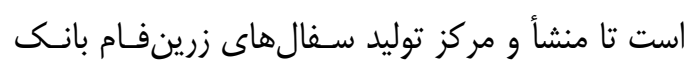


افزون بر اينها، دربارة لعابهاى زمينه و لايه هاى زريـن

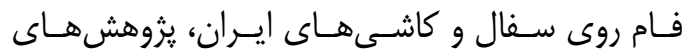
ديخرى نيز به انجام رسيده است. بـراى نمونـه، نتـايج

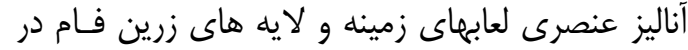

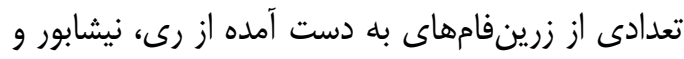

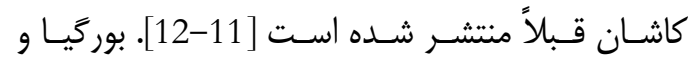

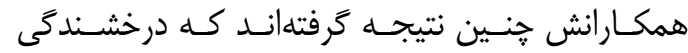
سفال هاى زرين فام ســدهاى ميـانى، ناشـى از حضـور

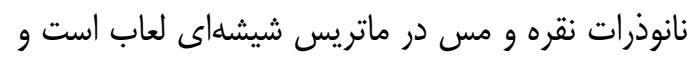
در نمونههايى كه لايه زرينفام متمايل به قرمز اسـت،

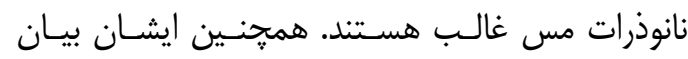

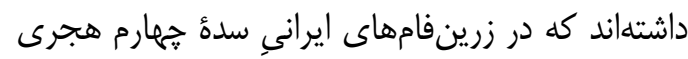
در مقايسه با زرينفامهاى سده هفتم هجـرى، اكسـيد

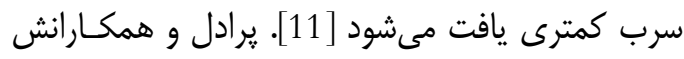

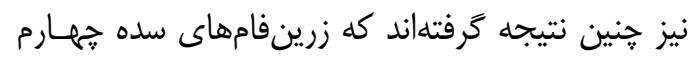

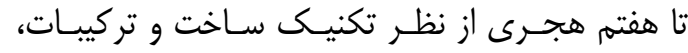
تفاوتها و شباهتهاى قابل توجهى دارند. براى نمان نمونه،

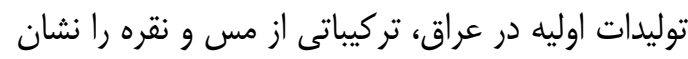

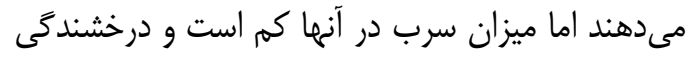

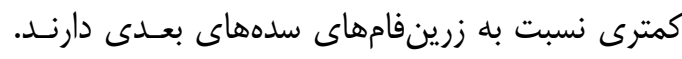

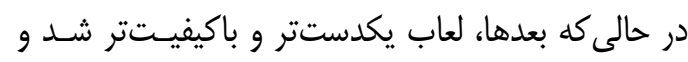

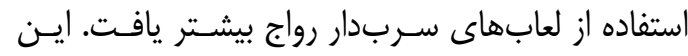

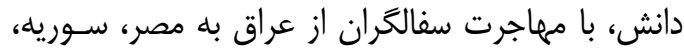

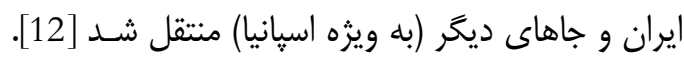

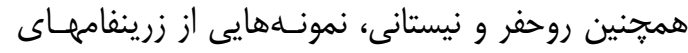

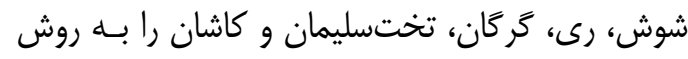

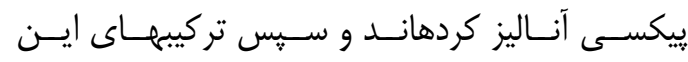

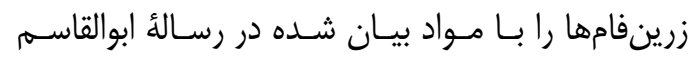

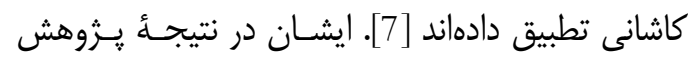

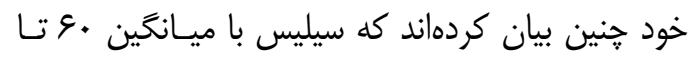

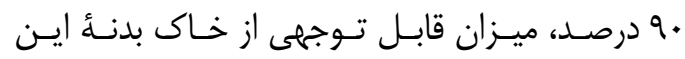

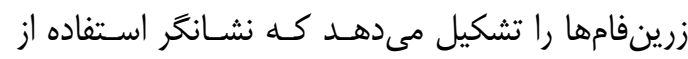

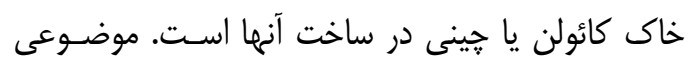

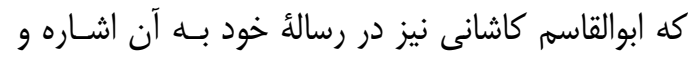
بدنهُ زرينفام را تركيبى از شكرسنى (سيليس)، شـخار

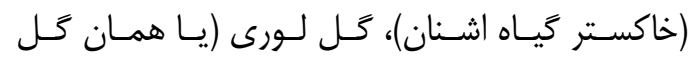

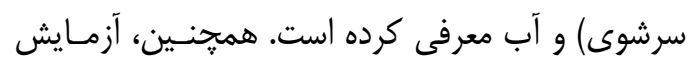

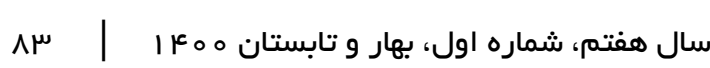

ويزگَى فناورى سفال در اين شهر را تبيين كرده اسـت.

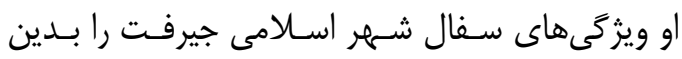

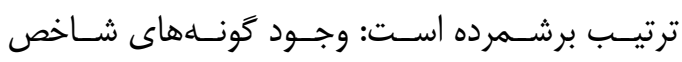
سدههاى نخست تا هفتم هجرى، توليـــ انبـوه سـفال، نمونههاى قابل مقايسه با ديكر مراكز تمدنى همزمـان تهان

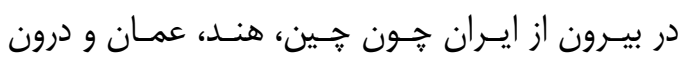

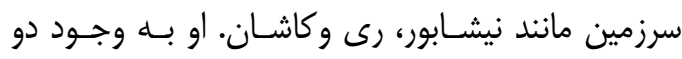

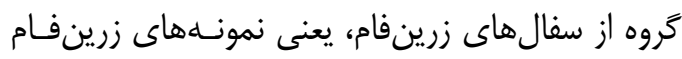

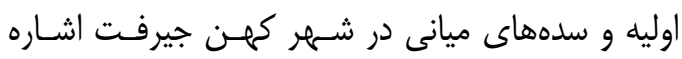

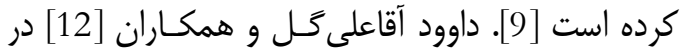

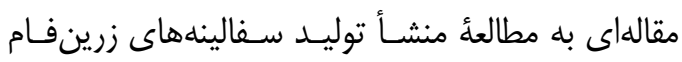

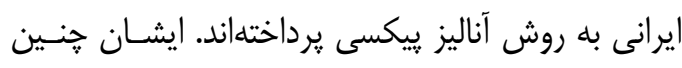

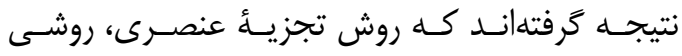

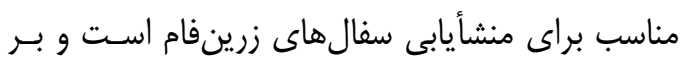

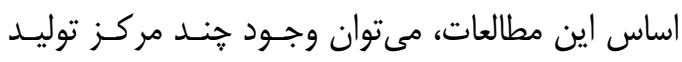

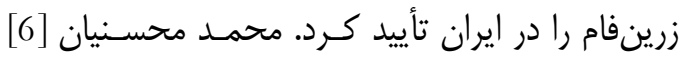
زرينفامهاى سدهاى ششم و هفتم هجرى به دسـت

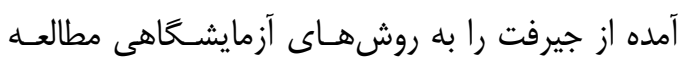

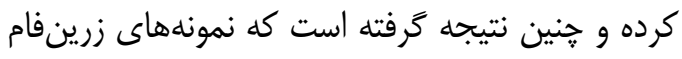
حاصل از كاوشهاى باستانشناسى در شهمر اسـلامى ندي

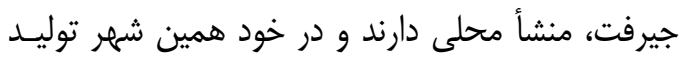
شدهاند. سعيد اميرحاجلو و همكاران [10] تعدادى از كاشىهاى

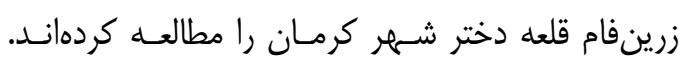
ايشان ضمن معرفى و طبقابندى كاشـىها، بـهـ تبيـين

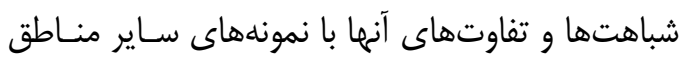

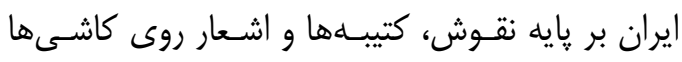

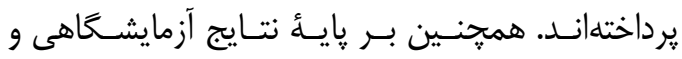

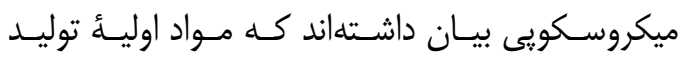
زرينفام در قلعهدختر كرمان، از منابع و معادن اطــراف

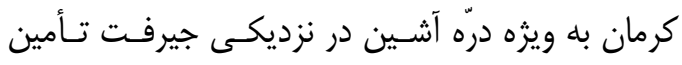

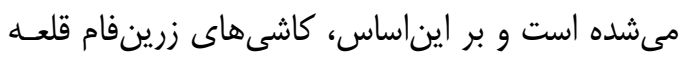

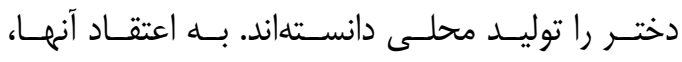

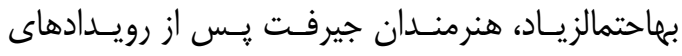

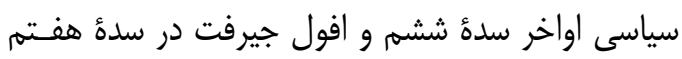
هجرى، به كرمان مهاجرت كرده و بــه توليـد زرينفـام ادامه دادهاند [10]. 
صدراسلام كمتر از نمونههاى سدهاى ميانى اسـلامى كئات

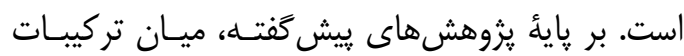

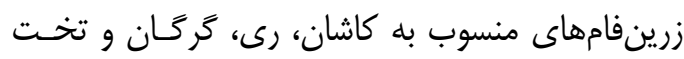

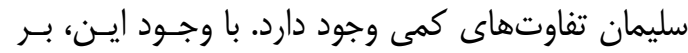

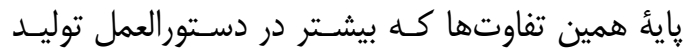

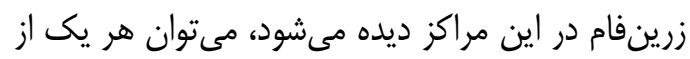

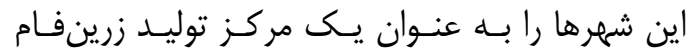

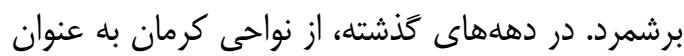

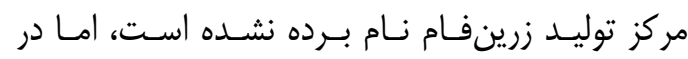

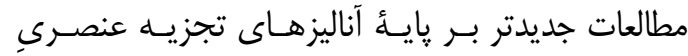
زرينفامهاى جيرفت و قلعلدختر كرمان و همجنين بـانـر

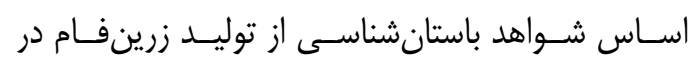

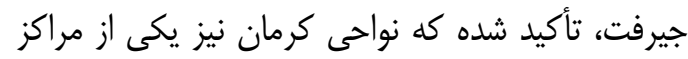

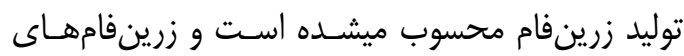

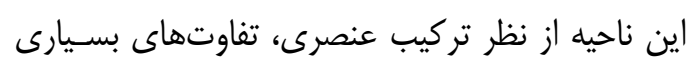

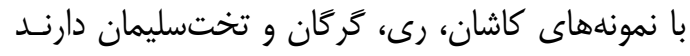

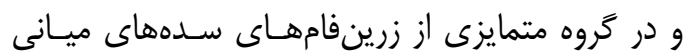

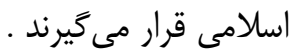

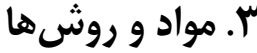

\section{ץ-1. بستر باستانشناختى نمونههاى مورد}

مطالعه

ارى كهن بهم، در شمال شرقى شهر امـروزى بـمه و در

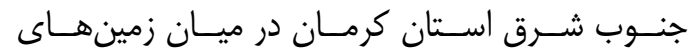

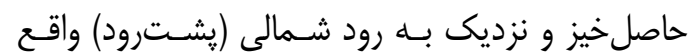

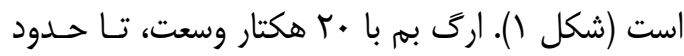
مال ب...

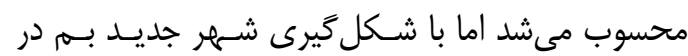

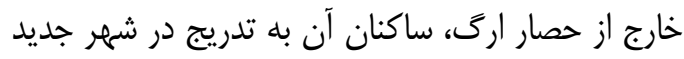

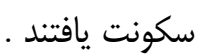

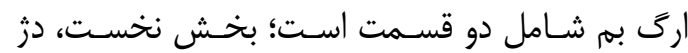
حكومتى يا حاكمنشين است كه روى تيـهاي بـ بـا بسـتر

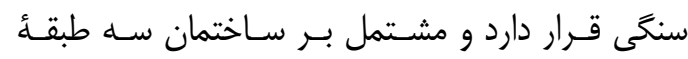

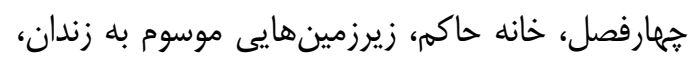

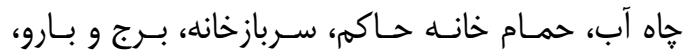

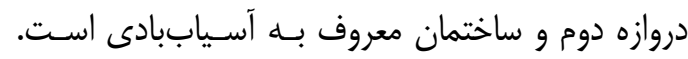

لعاب نمونهها نشان داده كـهـ بيشـترين درصــ عناصـر

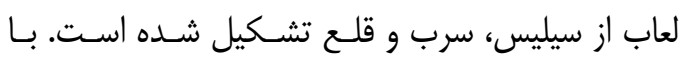

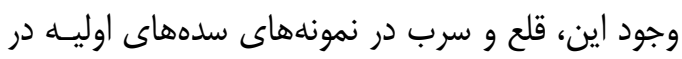

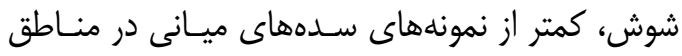

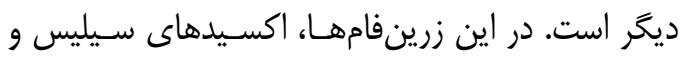

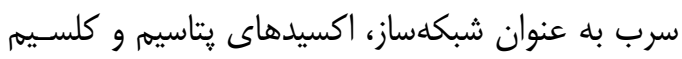

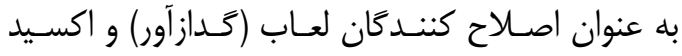
آلومينيوم به عنوان كمك شبكهساز به كار رفته اسـت.

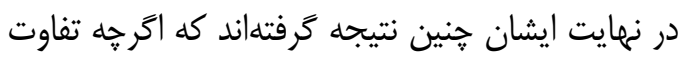
ميان زرينفامهاى مناطق مختلف ايـران در ســدهاى

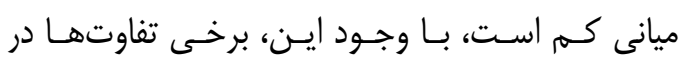

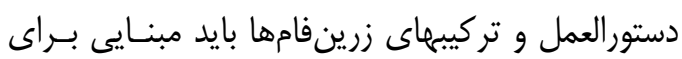

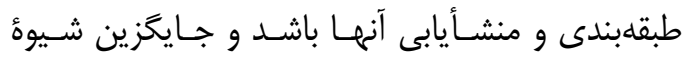
طبقابندى بر اساس نقوش شود [7]. علاوه بر اين، با استفاده از تحليل آمـاري نتـايج آنـاليز

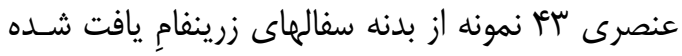
از رى، الموت، مراغه، كاشان، تخت سليمان و جيرفت، رئه خاستخاه و محل توليد برخى سفالمهاى زرين فام ايـران

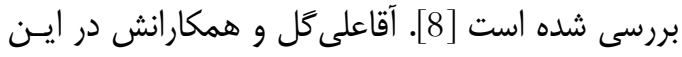

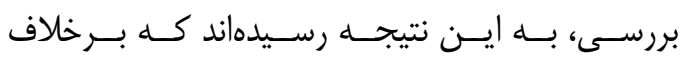

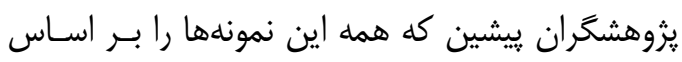
نوع نقوش و رنغ لعاب به كاشان نسبت دادهاند، نتايج

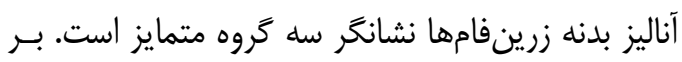

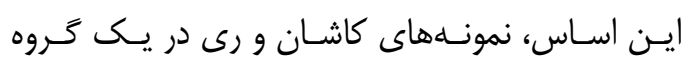

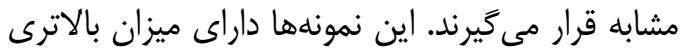

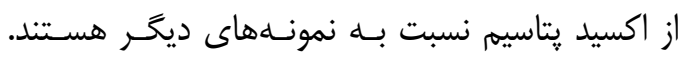

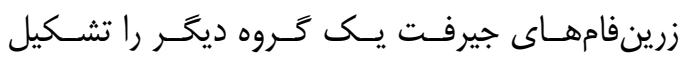

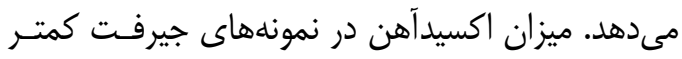

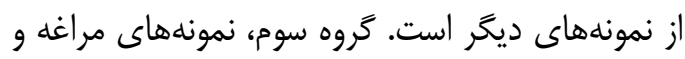

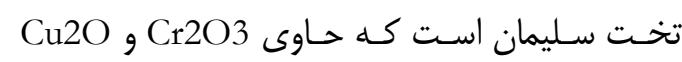

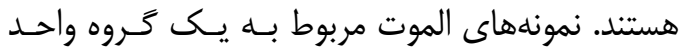

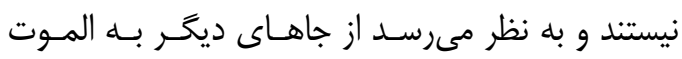
منتقل شدهاند [8]. بنابراين، مقايسه و جمعبندى نتايج يزوهشهاى يناى ييشين

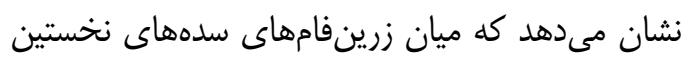
و سدهاى ميانى اسلامى تفاوتهايى در ميزان قلـع و مئن سرب وجود دارد، جنان كه قلـع و سـرب در نمونسهاى تلهاى 
فعاليتهـــاى باستان شــاختى، مرمتــى و حفــاظتى در مجموعه حاكمنشين و عاملنشين ارگ بهم، در سالهاى كذشته به صورت مستمر صورت يذيرفته و به كشـف و و شناسايى مواد فرهنگى ارزشمندى منجــر شــده اسـت.

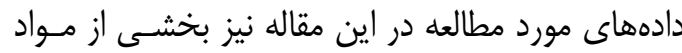

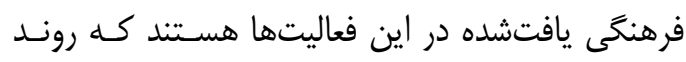

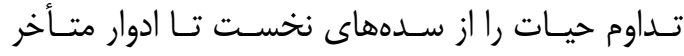
اسلامى نشان مىدهند.
بخش دوم ارگى، مردمنشين يـا عاملنشـين اسـت كـه

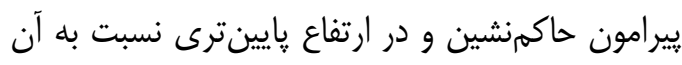
قرار دارد و دورتادور آن را حصارى محكم و خندقى فر فرا گرفته است [15-16]. بخش عامهنشين ارگ بم شامل عناصر مختلف شهرى مانند بازار، تكيه، مسجد جـامع،

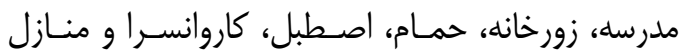

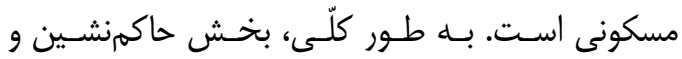

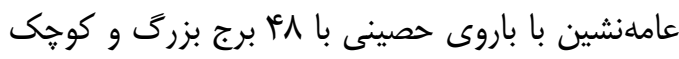

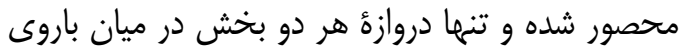
جنوبى مردمنشين جاسازى شده است [16].

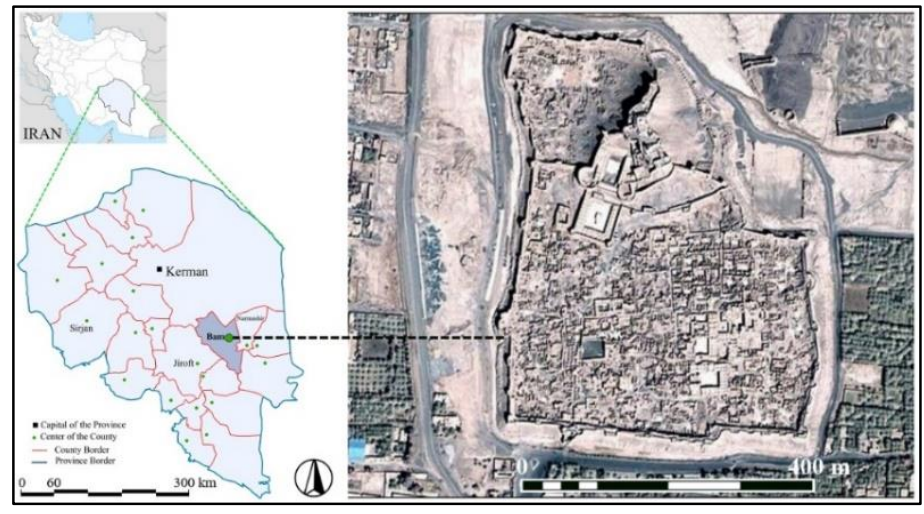

شكل ا: نقشه شهرستان بم طبق آخرين تقسيمات در سال يوسا (www.amar.org.ir) و موقعيت مكانى بم در استان كرمان (Unesco.org)

Fig. 1: The map of Bam in Kerman Province and Iran (Unesco.org; www.amar.org.ir)

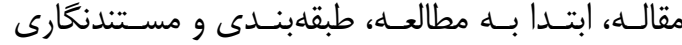
مجموعة قطعات سفال زرينفام در دو بخش نمايشـاه

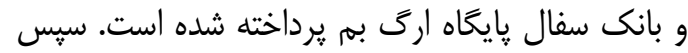

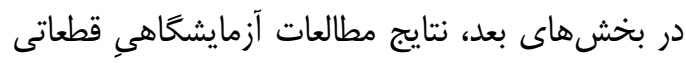

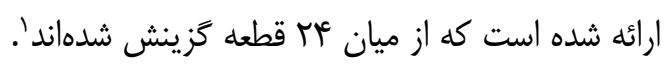

\section{ץ-r.r. جامعd آمارى مورد مطالعه}

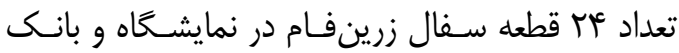

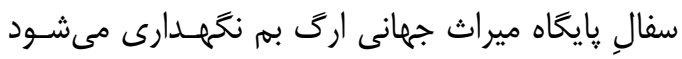
كه در فعاليتهاى باستانشناختى، آواربردارى، حفاظـت نكاهـ

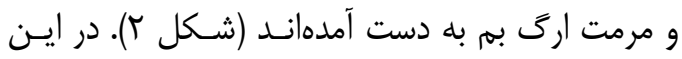

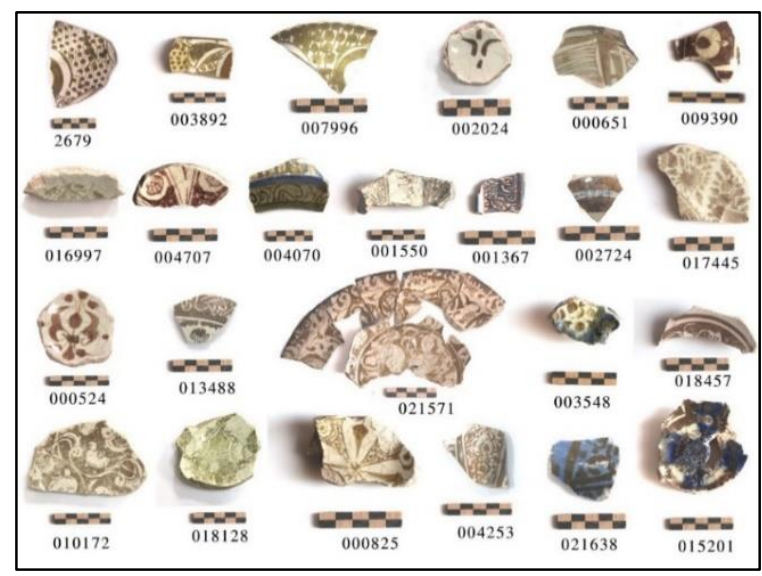

شكل ז: مجموعه سفال هاى زرينفام بانك سفال و نمايشگاه ارگ قديم بم

Fig. 2: The lustrewares in the pottery bank and exhibition of Arg-e Bam 
سفال هاى مورد مطالعه، بر اساس نقش به درشـتنقش

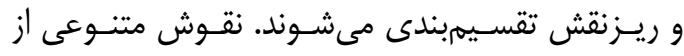

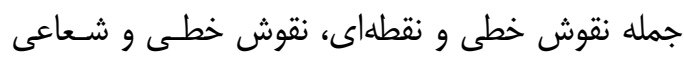

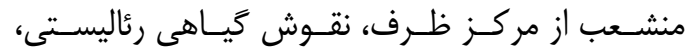

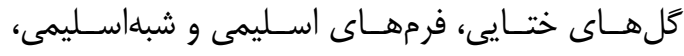
ترنجها، كتيبههاى خط نسخ و تعليـق يـا شـبه كتيبهها، نقوش هندسى به صورت قابهاى مسـتطيل شـكل و دواير متحدالمركز تو در تو، جهرههاى منـولى، نقـوش

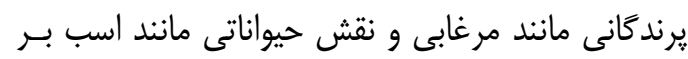
سطح سفال هاى زرينفام ارگ بم ديده مىشود.

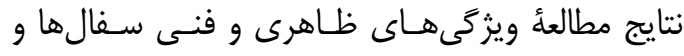

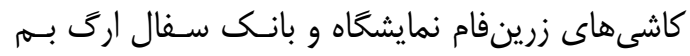

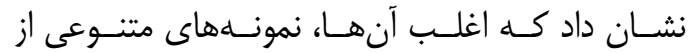

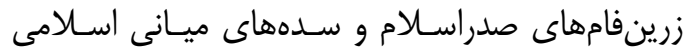

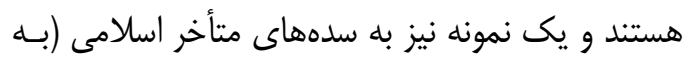
احتمال زياد، صفوى) تعلق دارد (جدول (). اين موضوع

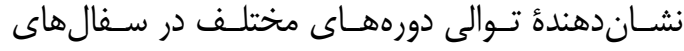

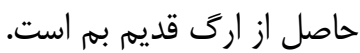

\section{ץ-". معرفى و طبقلبندى سفالهاى زرينفام} ارَى بم سفالهاى زرينفام بانك سفال و نمايشگاه ارك بم در

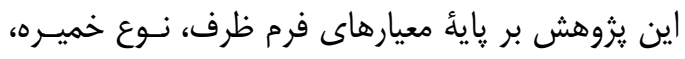

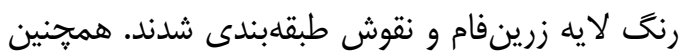

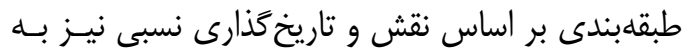

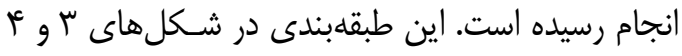

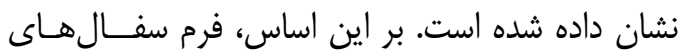

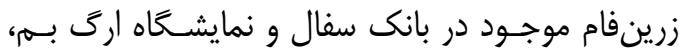
شامل بشقاب، كاسه، يياله و ظرف دهانه بسـته اسـت. اين نمونهها بر اساس خميره نيز سه دستأ اصلى خميره رسى، خميره بدل جينى و جينى را شامل مىشـوند. بــر

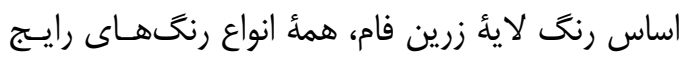
در لعابهاى زرينفام ـ از روشن تا تيره ـ در نمونههاى بانكى سفال و نمايشگاه ارك بم وجود دارنسـ؛ از جملـه

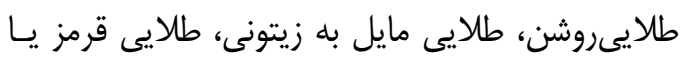

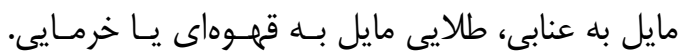

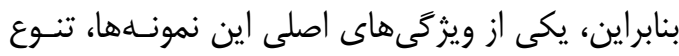

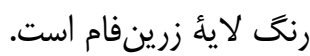

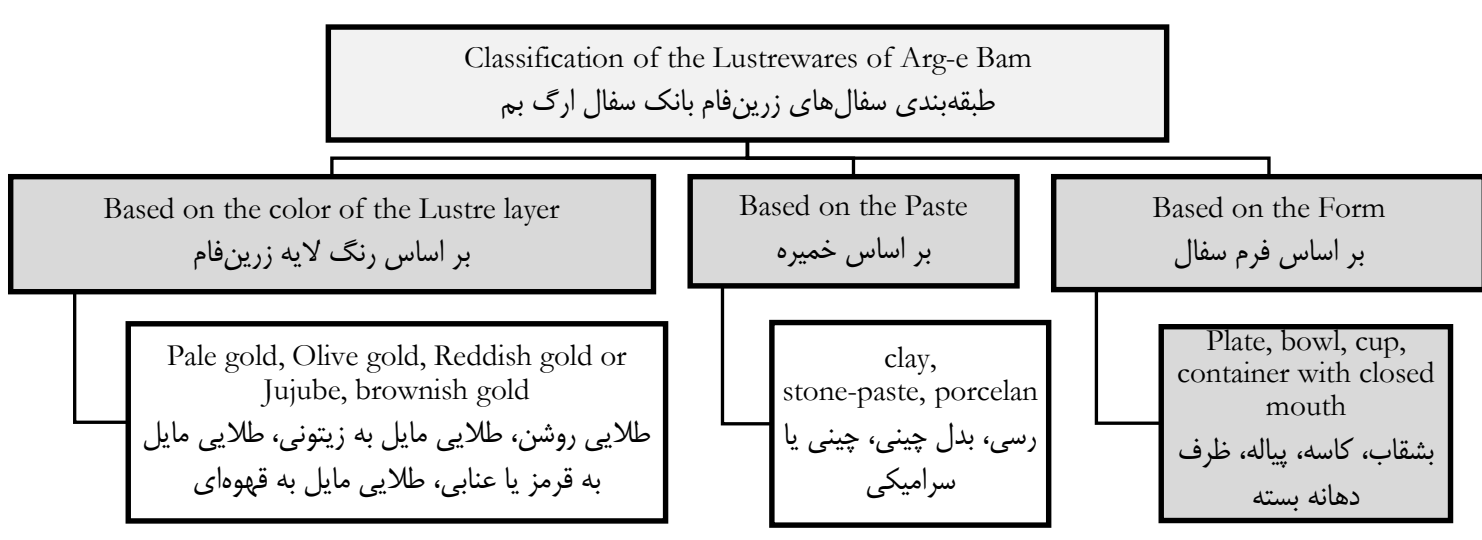

شكل "ا: طبقهبندى سفال هاى زرينفام در نمايشگاه و بانك سفال ارى قديم بم بر اساس فرم ظرف، نوع خميره و رنح لايه زرينفام Fig. 3: Classification of the lustrewares of Arg-e Bam based on the form, paste, and color of lustre layer 
بنونه

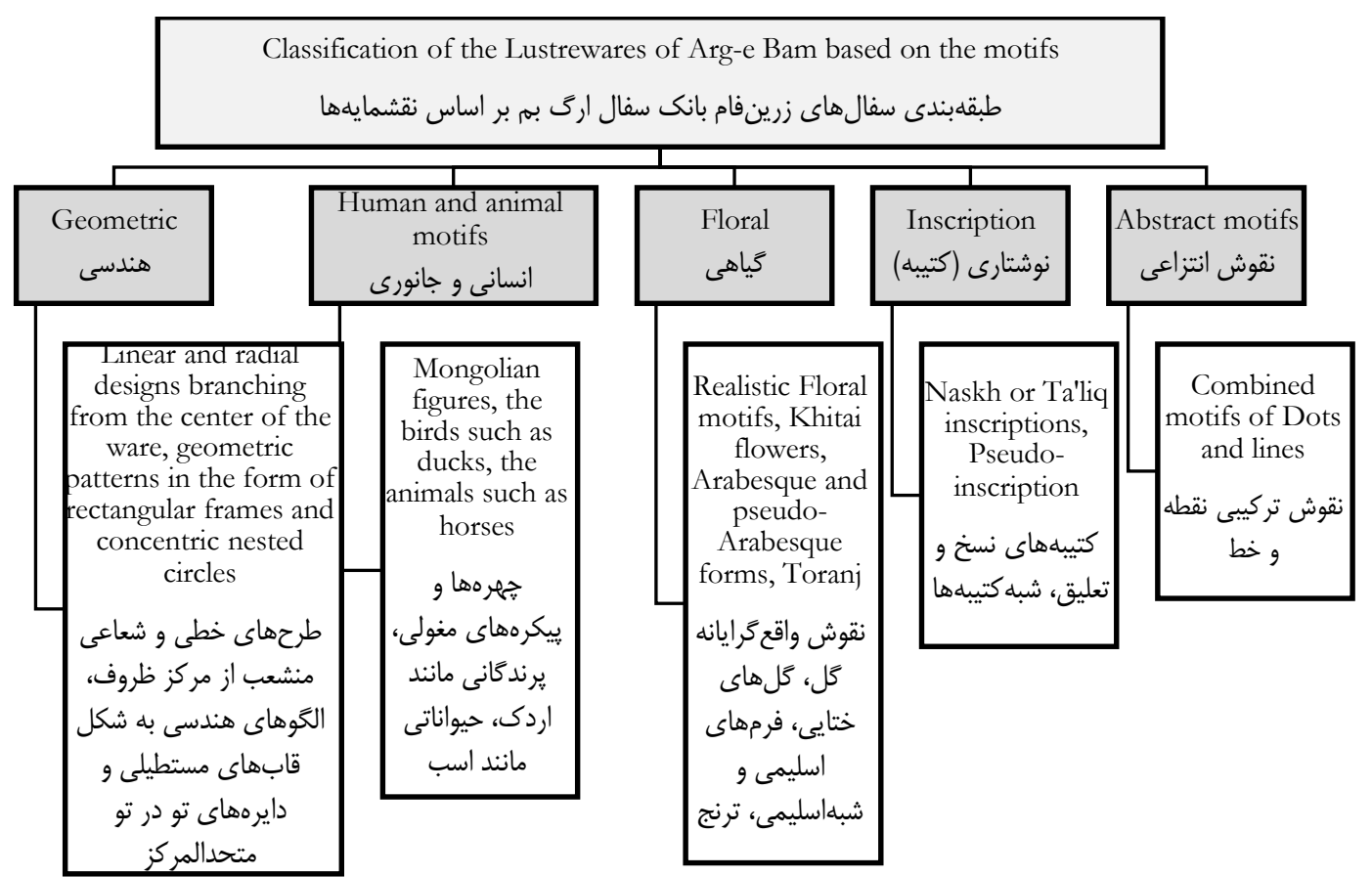

شكل זٔ: طبقهبندى سفالهاى زرينفام در نمايشگاه و بانك سفال ارگ قديم بم بر اساس نقش : B.

Fig. 4: Classification of the lustrewares of Arg-e Bam based on the motifs

جدول ا: كاهنگارى مقايسهاى و نسبى سفال هاى زرينفام مورد مطالعه

Table 1: Relative chronology of the lustrewares of Arg-e Bam

\begin{tabular}{|c|c|c|c|c|c|c|c|}
\hline & $\begin{array}{l}\text { Code of the } \\
\text { Sample } \\
\text { شماره قطعه }\end{array}$ & $\begin{array}{l}\text { Paste } \\
\text { خميره }\end{array}$ & $\begin{array}{l}\text { Thickness } \\
\text { (mm) } \\
\text { ضخامت }\end{array}$ & $\begin{array}{l}\text { Color of the Lustre glaze } \\
\text { رنغ لايه زرينفام }\end{array}$ & $\begin{array}{l}\text { Relative dating } \\
\text { كاهنخارى نسبى }\end{array}$ & $\begin{array}{c}\text { Referenc } \\
\text { e } \\
\text { هنبع }\end{array}$ & $\begin{array}{c}\text { Location of Excavation } \\
\text { مكان كشف }\end{array}$ \\
\hline 1 & 021571 & $\begin{array}{c}\text { Stone-paste } \\
\text { بدل جينى }\end{array}$ & 3 & $\begin{array}{c}\text { Olive gold } \\
\text { طلايى مايل به زيتونى }\end{array}$ & $\begin{array}{c}\text { 6-7AH/ 12- } \\
13 \mathrm{AD}\end{array}$ & {$[17-18]$} & 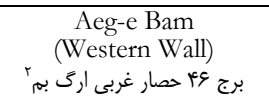 \\
\hline 2 & 000524 & $\begin{array}{l}\text { Stone-paste } \\
\text { بدل جينى }\end{array}$ & 3 & $\begin{array}{l}\text { Brownish gold } \\
\text { طلايى مايل به قهواى }\end{array}$ & $\begin{array}{c}\text { 6-7 AH/ 12- } \\
13 \mathrm{AD}\end{array}$ & {$[17,19]$} & $\begin{array}{c}\text { Aeg-e Bam (Western } \\
\text { wall) } \\
\text { اركى بمى (باروى غر) }\end{array}$ \\
\hline 3 & 018128 & $\begin{array}{c}\text { Stone-paste } \\
\text { بدل جينى }\end{array}$ & 5 & $\begin{array}{c}\text { Olive gold } \\
\text { طلايى مايل به زيتونى }\end{array}$ & $?$ & $?$ & $\begin{array}{c}\text { Aeg-e Bam (In front of } \\
\text { the bakery) } \\
\text { ارك بم (مقابل نانوايى) }\end{array}$ \\
\hline 4 & 000825 & $\begin{array}{l}\text { Stone-paste } \\
\text { بدل جينى }\end{array}$ & 6 & $\begin{array}{c}\text { Olive gold } \\
\text { طلايى مايل به زيتونى }\end{array}$ & $\begin{array}{c}\text { 6-7AH/ 12- } \\
13 \mathrm{AD}\end{array}$ & [19] & $\begin{array}{l}\text { Aeg-e Bam (Northern } \\
\text { wall) } \\
\text { ارك بمالى) (باروى }\end{array}$ \\
\hline 5 & 001367 & $\begin{array}{l}\text { Stone-paste } \\
\text { بدل קينى }\end{array}$ & 5 & $\begin{array}{l}\text { Reddish gold or Jujube } \\
\text { طلايى مايل به قرمز يا عنابى }\end{array}$ & $\begin{array}{c}\text { 6-7AH/ 12- } \\
13 \mathrm{AD}\end{array}$ & [17] & 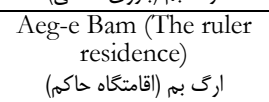 \\
\hline 6 & 004707 & $\begin{array}{c}\text { Stone-paste } \\
\text { بدل جينى }\end{array}$ & 4 & $\begin{array}{l}\text { Reddish gold or Jujube } \\
\text { طلايى مايل به قرمز يا عنابى }\end{array}$ & $\begin{array}{c}\text { 6-7AH/12- } \\
13 \mathrm{AD}\end{array}$ & [20] & 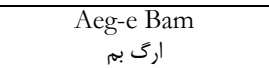 \\
\hline 7 & 003548 & $\begin{array}{c}\text { Stone-paste } \\
\text { بدل קينى }\end{array}$ & 6 & $\begin{array}{l}\text { Brownish gold } \\
\text { طلايى مايل به قهواى }\end{array}$ & $\begin{array}{c}\text { 6-7AH/12- } \\
13 \mathrm{AD}\end{array}$ & [21] & 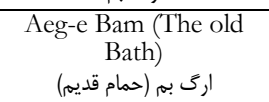 \\
\hline 8 & 004253 & $\begin{array}{c}\text { Stone-paste } \\
\text { بدل جينى }\end{array}$ & 3 & $\begin{array}{c}\text { Olive gold } \\
\text { طلايى مايل به زيتونى }\end{array}$ & $\begin{array}{c}\text { 6-7AH/12- } \\
13 \mathrm{AD}\end{array}$ & [2] & - \\
\hline 9 & 002724 & $\begin{array}{c}\text { Stone-paste } \\
\text { بدل جينى }\end{array}$ & 2 & $\begin{array}{l}\text { Brownish gold } \\
\text { طلايى مايل به قهوماى }\end{array}$ & $?$ & $?$ & 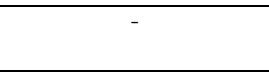 \\
\hline 10 & 017445 & $\begin{array}{l}\text { Porcelain } \\
\text { بدل جينى }\end{array}$ & 7 & $\begin{array}{l}\text { Pale gold } \\
\text { طلايى روشن }\end{array}$ & Safavid & {$[1-2,17]$} & 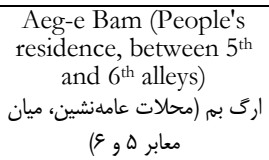 \\
\hline 11 & 002024 & $\begin{array}{c}\text { Stone-paste } \\
\text { بدل جينى }\end{array}$ & 3 & $\begin{array}{l}\text { Brownish gold } \\
\text { طلايى مايل به قهوماى }\end{array}$ & $\begin{array}{c}\text { 6-7AH/ 12- } \\
13 \mathrm{AD}\end{array}$ & [22] & 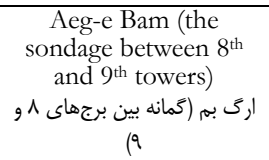 \\
\hline 12 & 021638 & Stone-paste & 2 & Brownish gold & $6-7 \mathrm{AH} / 12-$ & {$[21]$} & Aeg-e Bam (tower no. \\
\hline
\end{tabular}




\begin{tabular}{|c|c|c|c|c|c|c|c|}
\hline & & بدل پينى & & طلايى مايل به قهوهاى & $13 \mathrm{AD}$ & & ارى بم (برج ا) \\
\hline 13 & 004070 & $\begin{array}{c}\text { Stone-paste } \\
\text { بدل خينى }\end{array}$ & 4 & $\begin{array}{l}\text { Pale gold } \\
\text { طلايى روشن }\end{array}$ & $\begin{array}{c}\text { 6-7AH/ 12- } \\
13 \mathrm{AD}\end{array}$ & [23] & $\begin{array}{c}\text { Aeg-e Bam } \\
\text { اركى بمى }\end{array}$ \\
\hline 14 & 001550 & $\begin{array}{c}\text { Stone-paste } \\
\text { بدل خينى }\end{array}$ & 5 & $\begin{array}{c}\text { Olive gold } \\
\text { طايیى مايل به زيتونى }\end{array}$ & $\begin{array}{c}\text { 6-7AH/ 12- } \\
\text { 13AD }\end{array}$ & [19] & - \\
\hline 15 & 007996 & $\begin{array}{l}\text { Clay } \\
\text { رسى }\end{array}$ & 3 & $\begin{array}{l}\text { Pale gold } \\
\text { طايى روشن }\end{array}$ & $\begin{array}{l}\text { 3-4AH/ 9- } \\
\text { 10AD }\end{array}$ & $\begin{array}{l}{[3,19,} \\
23-25]\end{array}$ & $\begin{array}{l}\text { Aeg-e Bam (west of the } \\
\text { Sistani house) } \\
\text { ارى بم (غرب خانه سيستانى) }\end{array}$ \\
\hline 16 & 2679 & $\begin{array}{l}\text { Clay } \\
\text { رسى }\end{array}$ & 3 & $\begin{array}{c}\text { Olive gold } \\
\text { طلايى مايل به زيتونى }\end{array}$ & $\begin{array}{c}\text { 3-4AH/ 9- } \\
10 \mathrm{AD}\end{array}$ & $\begin{array}{l}{[3,19,} \\
23-25]\end{array}$ & 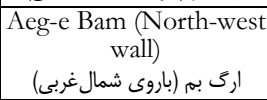 \\
\hline 17 & 003892 & $\begin{array}{l}\text { Clay } \\
\text { رسى }\end{array}$ & 5 & $\begin{array}{l}\text { Olive gold and Reddish } \\
\text { gold } \\
\text { طلايى مايل به زيتونى و قرمز }\end{array}$ & $\begin{array}{l}\text { 3-4AH/ 9- } \\
10 \mathrm{AD}\end{array}$ & {$[26]$} & 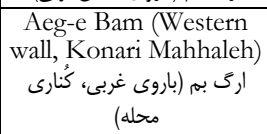 \\
\hline 18 & 000651 & $\begin{array}{l}\text { Clay } \\
\text { رسى }\end{array}$ & 4 & $\begin{array}{l}\text { Pale gold } \\
\text { طلايى روشن }\end{array}$ & $\begin{array}{l}\text { 3-4AH/ 9- } \\
10 \mathrm{AD}\end{array}$ & $?$ & $\begin{array}{c}\text { Aeg-e Bam (Western } \\
\text { wall) } \\
\text { ارگ بم (باروى غربى) }\end{array}$ \\
\hline 19 & 018457 & $\begin{array}{c}\text { Stone-paste } \\
\text { بدل جينى }\end{array}$ & 3 & $\begin{array}{l}\text { Brownish gold } \\
\text { طلايى مايل به قهوماى }\end{array}$ & $?$ & $?$ & $\begin{array}{c}\text { Aeg-e Bam (Mir Akbar) } \\
\text { ارى بم (ميراكبر) }\end{array}$ \\
\hline 20 & 015201 & $\begin{array}{c}\text { Stone-paste } \\
\text { بدل קينى }\end{array}$ & 5 & $\begin{array}{l}\text { Brownish gold } \\
\text { طلايى مايل به قهوماى }\end{array}$ & $\begin{array}{c}\text { 6-7AH/ 12- } \\
\text { 13AD }\end{array}$ & [22] & $\begin{array}{c}\text { Aeg-e Bam (North of } \\
\text { tower no. 7) } \\
\text { ارق بم (شمال برج V }\end{array}$ \\
\hline 21 & 016997 & $\begin{array}{c}\text { Stone-paste } \\
\text { بدل קينى }\end{array}$ & 4 & $\begin{array}{l}\text { Pale gold } \\
\text { طلايى روشن }\end{array}$ & $?$ & $?$ & 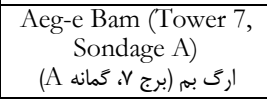 \\
\hline 22 & 010172 & $\begin{array}{c}\text { Stone-paste } \\
\text { بدل جينى }\end{array}$ & 4 & $\begin{array}{c}\text { Olive gold } \\
\text { طلايى مايل به زيتونى }\end{array}$ & $\begin{array}{c}\text { 6-7AH/ 12- } \\
13 \mathrm{AD}\end{array}$ & {$[17]$} & $\begin{array}{c}\text { Aeg-e Bam (Mir house) } \\
\text { ارى بم (خانه مير) }\end{array}$ \\
\hline 23 & 009390 & $\begin{array}{l}\text { Stone-paste } \\
\text { بدل קينى }\end{array}$ & 3 & $\begin{array}{l}\text { Reddish gold or Jujube } \\
\text { طلايى مايل به قرمز يا عنابى }\end{array}$ & $5 \mathrm{AH} / 11 \mathrm{AD}$ & [9] & $\begin{array}{c}\text { Aeg-e Bam (North of } \\
\text { Mir house) } \\
\text { ارى بمانه (شمال خير) }\end{array}$ \\
\hline 24 & 013488 & $\begin{array}{c}\text { Stone-paste } \\
\text { بدل خينى }\end{array}$ & 4 & $\begin{array}{c}\text { Olive gold } \\
\text { طلايى مايل به زيتونى }\end{array}$ & $\begin{array}{c}\text { 6-7AH/ 12- } \\
13 \mathrm{AD}\end{array}$ & {$[27]$} & $\begin{array}{c}\text { Aeg-e Bam (Stable) } \\
\text { ارى بم (اصطبل) }\end{array}$ \\
\hline
\end{tabular}

\section{ץ-ع. مطالعات آزمايشَّاهى نمونهها}

اندازمكيرى مىشود كه با استفاده از آن مىتوان غلظت

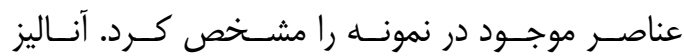
طيفهاى به دست آمــده بـــاى انــازهذيرى تركيبـات

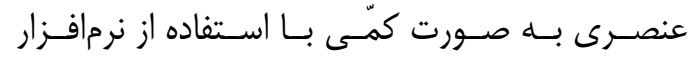
《GUPIXWIN》

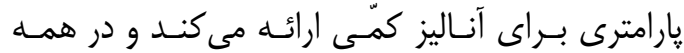

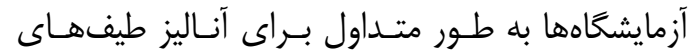

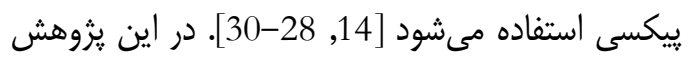

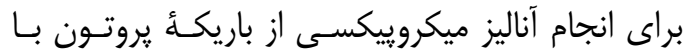

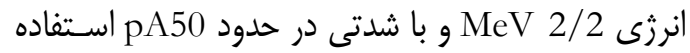

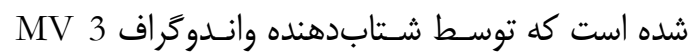
آزمايشخاه واندوكراف يزوهشگاه علوم و فنون هستهاى

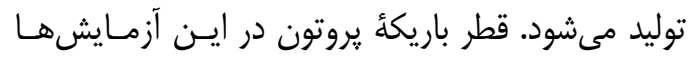
كمتر از • إميكرون تنظيم شده است. براى آشكارسازى آنى

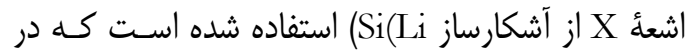

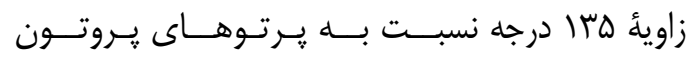

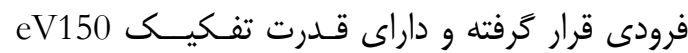

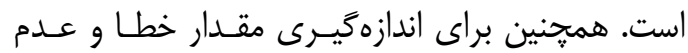

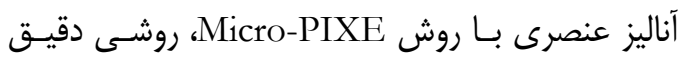
براى اندازمخيرى عناصـر اصـلى و كممقـدار در اشـياء

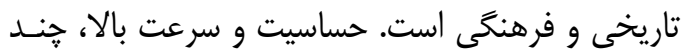

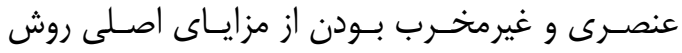

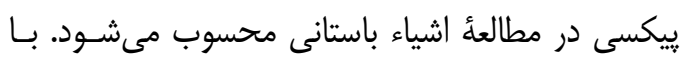

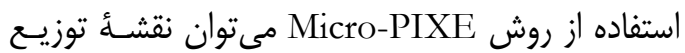

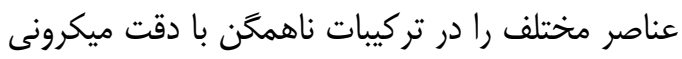

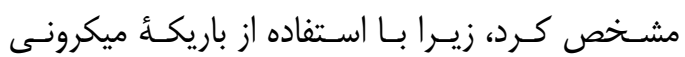
يروتون مىتوان سطح نمونه را اسكن كرد و تصـويرى

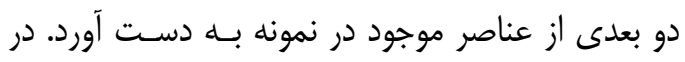

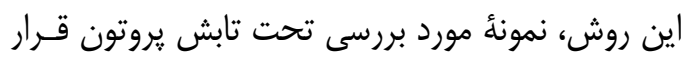

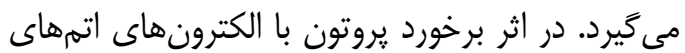

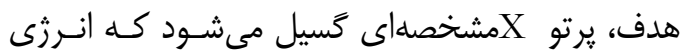

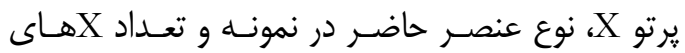

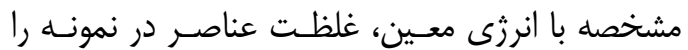

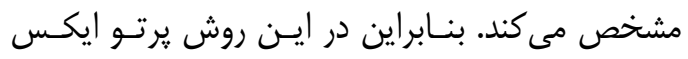

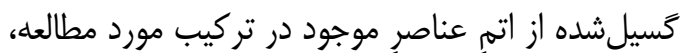

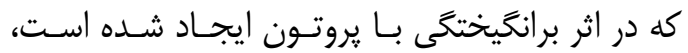


قطعه بر اساس معيارهاى بيان شده در سـطور ييشـين، براى آناليز انتخاب شده است.

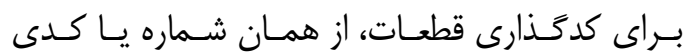

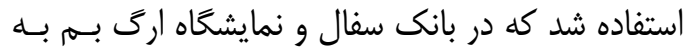

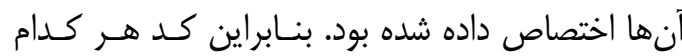

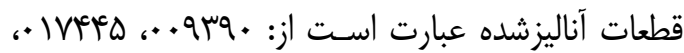

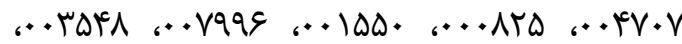

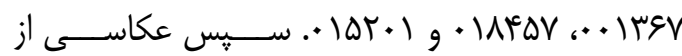

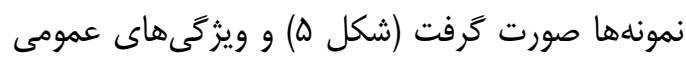
آنها در جدول مشخصات فنى سفال ثبت شد. لازم به

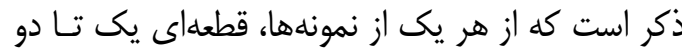
سانتىمترى جداسازى شد.

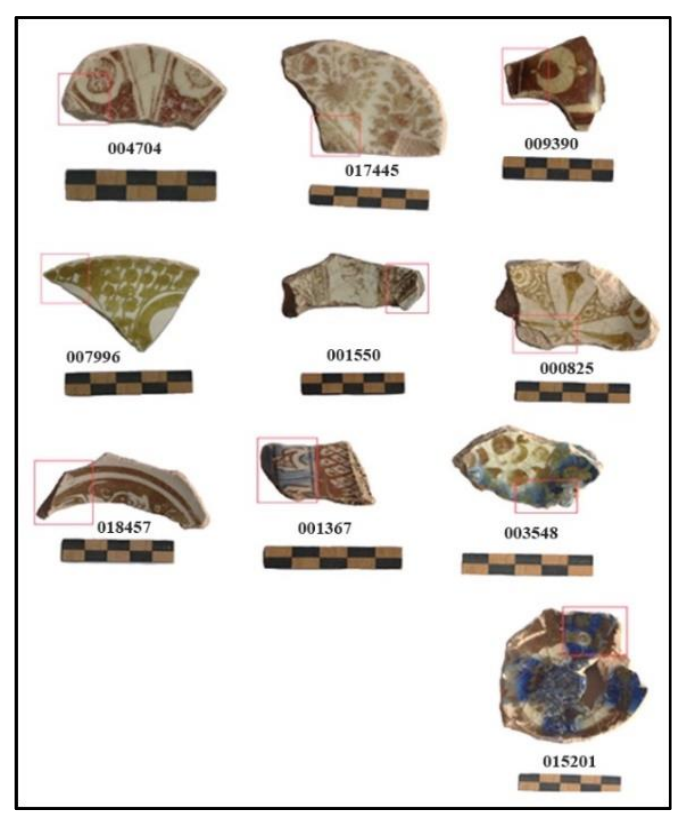

شكل ه: نمونهاى انتخاب شده و محل جداسازى آنها براى إى

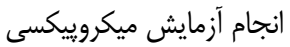

Fig. 5: Selected samples and the cutted sections to Micro-PIXE analysis

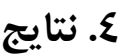

ع-1 آز آزمايث خميره بدنه

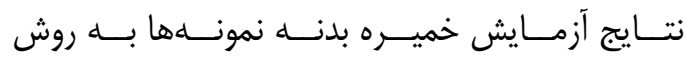

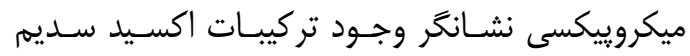

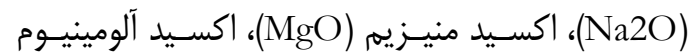

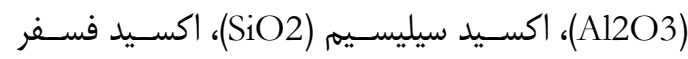

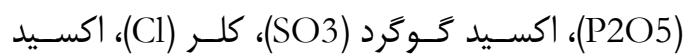
يتاسيم (K2O)، اكسيد كلسيم (CaO)، اكسيد تيتانيوم
دقت در اندازهيرى درصد وزنى عناصـر تشـكيلدهنده

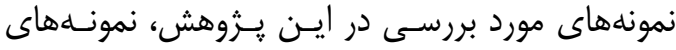

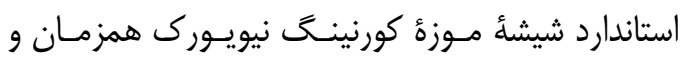
تحت شرايط يكسـان بـا نمونسهـهـا، مـورد آنـاليز قــرار كرفتند.

\section{س-0. نمونههاى انتخاب شده براى آناليز}

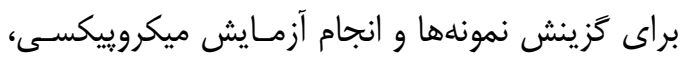

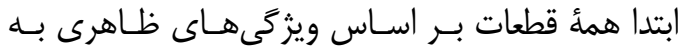

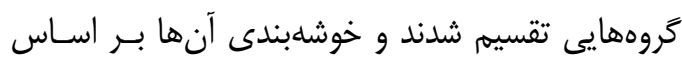
بيشترين ميزان تجانس و همسانى در رنغى لعاب، نقش و خميره صورت كرفت. سبس از هر خوشـهـ يـا حـروه، يك يا دو قطعة شاخص انتخاب شد. براى اين منظـور

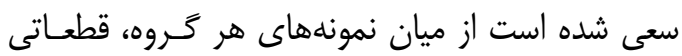

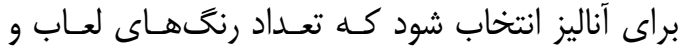

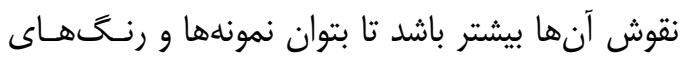

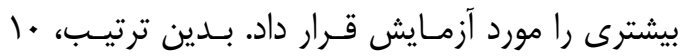
قطعه از ميان عَ قطعه براى انجـام آزمـايش انتخــاب

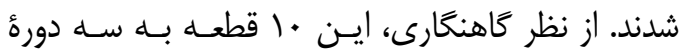

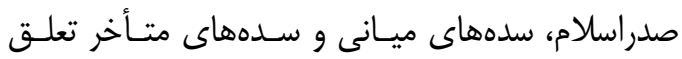

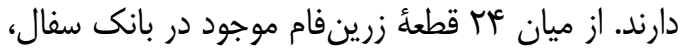

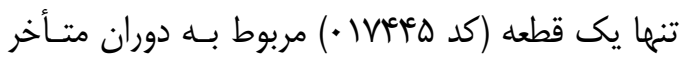

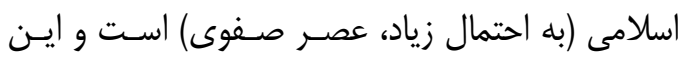

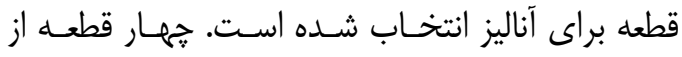

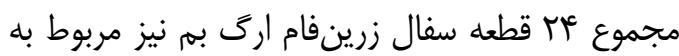

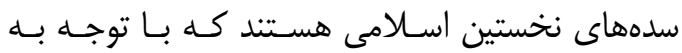

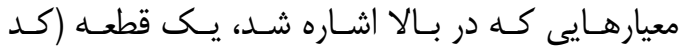

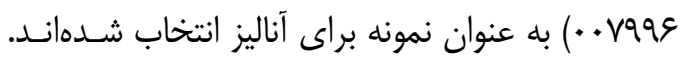

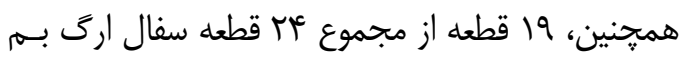

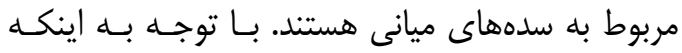

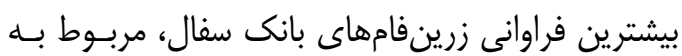

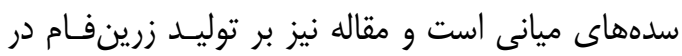

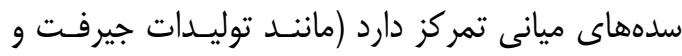

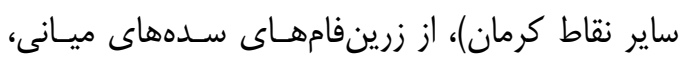

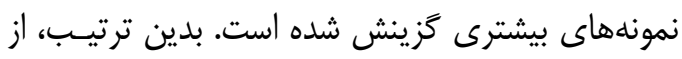

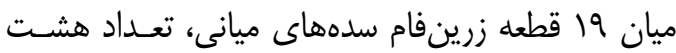


دانههاى كوجکتر شن، ماسه و سيلت با قابليت

نفوذيذيرى كم تشكيل يافته است [32]. مقايسٔ درصد وزنى عناصر بدنهُ سفال هاى مورد مطالعه

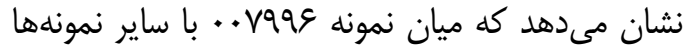

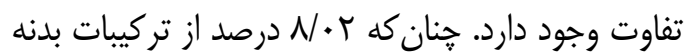

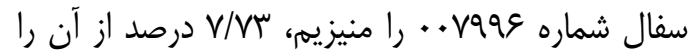

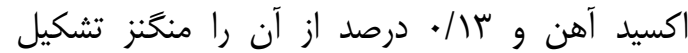
مىدهد كه بسيار بيشتر از نمونههاى ديخر است. همجنين درصد وزنى اكسيد سيليسيه در اين نمونه نيز نسبت به نمونههاى ديخر حدود • ب درصد كمتر است و

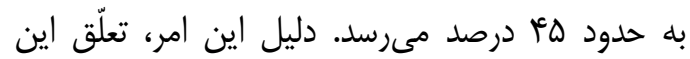

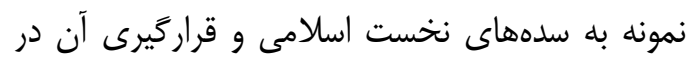
كَونئ سفالهاى زرينفام اوليه است. همان كونه كه ييشتر اشاره شد، أ قطعه از أب قطعه سفال مورد مطالعه، بر اساس ويزگگهاى سبكى و فنى، از نوع

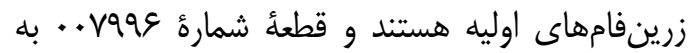
عنوان نمونه شاخص از ميان اين ههار قطعه براى آناليز انتخاب شده بود. ساير نمونهها به سدههاى ميانى إنى و يكى قطعه به سدهاى متأخر اسلامى تعلّق دارند و نهائ

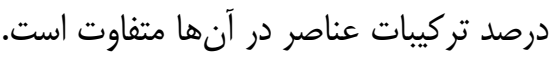

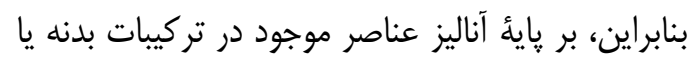

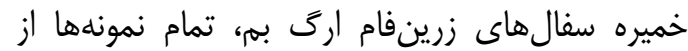
نظر نوع و درصد عناصر بدنه يكسان هستند و تنها نمونئ و99 .. از نظر تركيبات عنصرى كاملاً با بقيئ

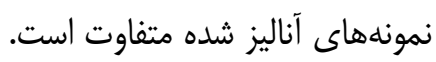

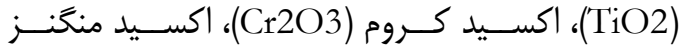

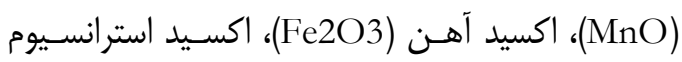

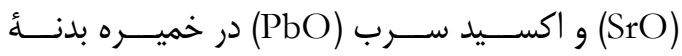
سفال هاى زرينفام ارگ بمى است (جدول ז؛ شـكلهاى

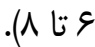
از نظر فراوانى و درصد وزنى، عناصر با بيشترين

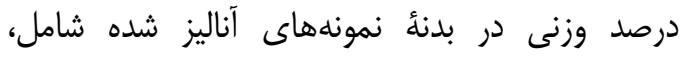

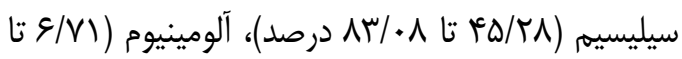

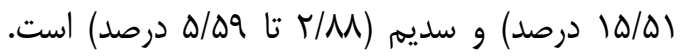

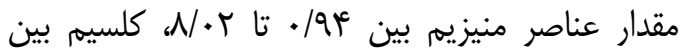

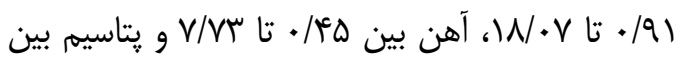

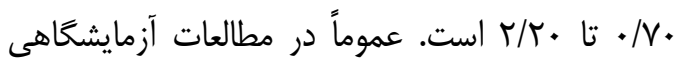

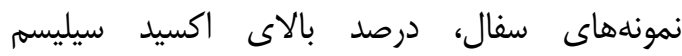
(سيليس) نشاندهندة رسوبى بودن محل تأمين مواد

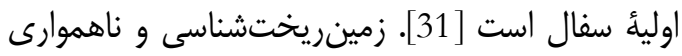

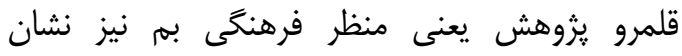

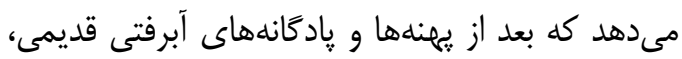

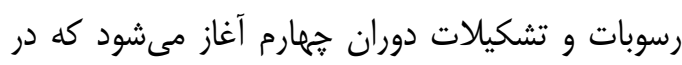
اصل همان تشكيلات دشت بم - نرماشير است،

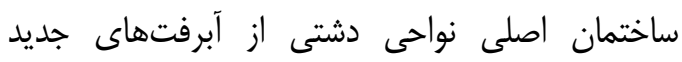

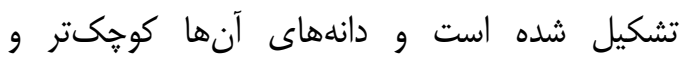
رنخشان روشنتر از آبرفتهاى قديمى به نظر أنر مىرسد.

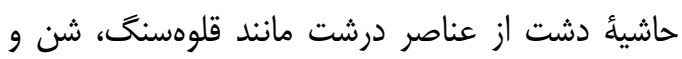
ريخ با قابليت نفوذيذيرى زياد و نواحى مركزى از درن

جدول r: نتايج آزمايش خميره بدنه نمونههاى مورد مطالعه با روش ميكروييكسى

Table 2: The analysis results of the paste of samples by Micro-PIXE

\begin{tabular}{|c|c|c|c|c|c|c|c|c|c|c|c|c|c|c|c|}
\hline sample & $\mathbf{N a}$ & $\mathbf{M g}$ & $\mathbf{A l}$ & $\mathbf{S i}$ & $\mathbf{P}$ & $\mathbf{S}$ & $\mathbf{C l}$ & $\mathbf{K}$ & $\mathbf{C a}$ & $\mathbf{T i}$ & $\mathbf{C r}$ & $\mathbf{M n}$ & $\mathbf{F e}$ & $\mathbf{S r}$ & $\mathbf{P b}$ \\
\hline $\mathbf{0 0 0 8 2 5}$ & 4.96 & 1.18 & 8.05 & 72.31 & 0.94 & 0.32 & 0.34 & 4.27 & 3.89 & 1.65 & 0.04 & 0.03 & 1.38 & 0.39 & nd \\
\hline $\mathbf{0 0 3 5 4 3}$ & 4.33 & 1.02 & 7.54 & 73.02 & 2.44 & nd & 0.37 & 2.99 & 4.13 & 1.75 & nd & nd & 1.30 & nd & nd \\
\hline $\mathbf{0 0 4 7 0 7}$ & 4.61 & 1.29 & 7.28 & 71.86 & 2.51 & 0.28 & 0.41 & 3.23 & 4.63 & 1.58 & nd & nd & 1.84 & nd & nd \\
\hline $\mathbf{0 0 7 9 9 6}$ & 2.98 & 6.95 & 12.71 & 36.70 & nd & nd & 0.25 & 1.31 & 26.52 & 0.91 & 0.21 & 0.30 & 10.28 & nd & nd \\
\hline $\mathbf{0 1 7 4 4 5}$ & 5.20 & 0.91 & 6.17 & 79.78 & 1.05 & 0.18 & 0.84 & 2.16 & 2.41 & 0.37 & nd & nd & 0.87 & nd & nd \\
\hline $\mathbf{0 1 8 4 5 7}$ & 4.86 & 1.51 & 5.64 & 71.41 & 0.97 & 0.50 & 0.34 & 3.75 & 6.17 & 1.38 & 0.04 & 0.06 & 2.89 & nd & 1.02 \\
\hline $\mathbf{0 0 1 3 6 7}$ & 4.62 & 1.41 & 7.27 & 71.92 & 1.43 & 0.18 & 0.68 & 3.41 & 4.52 & 1.38 & nd & 0.06 & 2.54 & nd & 0.85 \\
\hline $\mathbf{0 1 5 2 0 1}$ & 5.78 & 1.34 & 10.91 & 68.71 & 1.32 & 0.39 & 0.48 & 4.37 & 3.54 & 1.42 & nd & nd & 1.24 & nd & 0.25 \\
\hline $\mathbf{0 0 9 3 9 0}$ & 4.99 & 1.02 & 8.90 & 72.26 & 1.88 & 0.32 & nd & 3.72 & 3.47 & 1.62 & nd & 0.06 & 1.05 & nd & nd \\
\hline $\mathbf{0 0 1 5 5 0}$ & 4.16 & 1.26 & 7.98 & 71.41 & 1.29 & 0.25 & 0.51 & 6.26 & 3.40 & 1.38 & nd & nd & 1.46 & nd & 0.46 \\
\hline
\end{tabular}




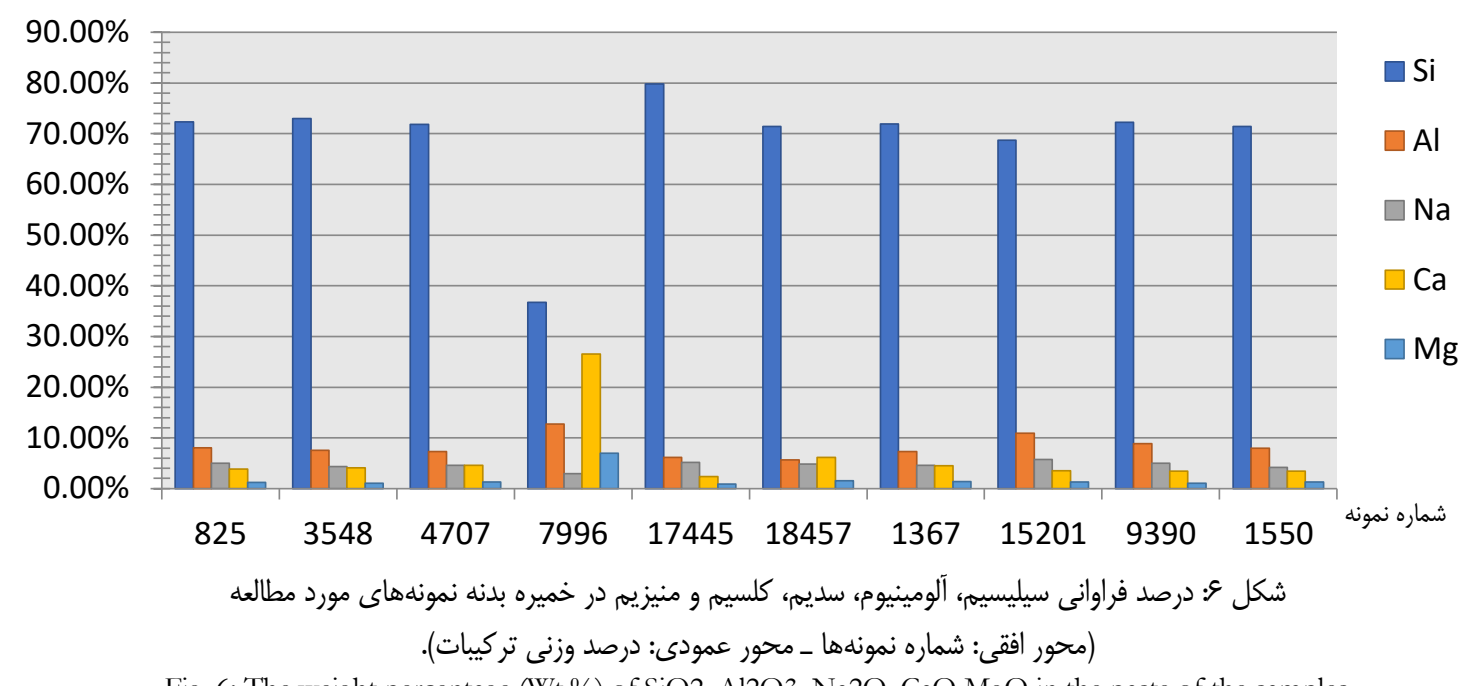

Fig. 6: The weight percentage (Wt.\%) of $\mathrm{SiO} 2, \mathrm{Al} 2 \mathrm{O} 3, \mathrm{Na} 2 \mathrm{O}, \mathrm{CaO} \mathrm{MgO}$ in the paste of the samples

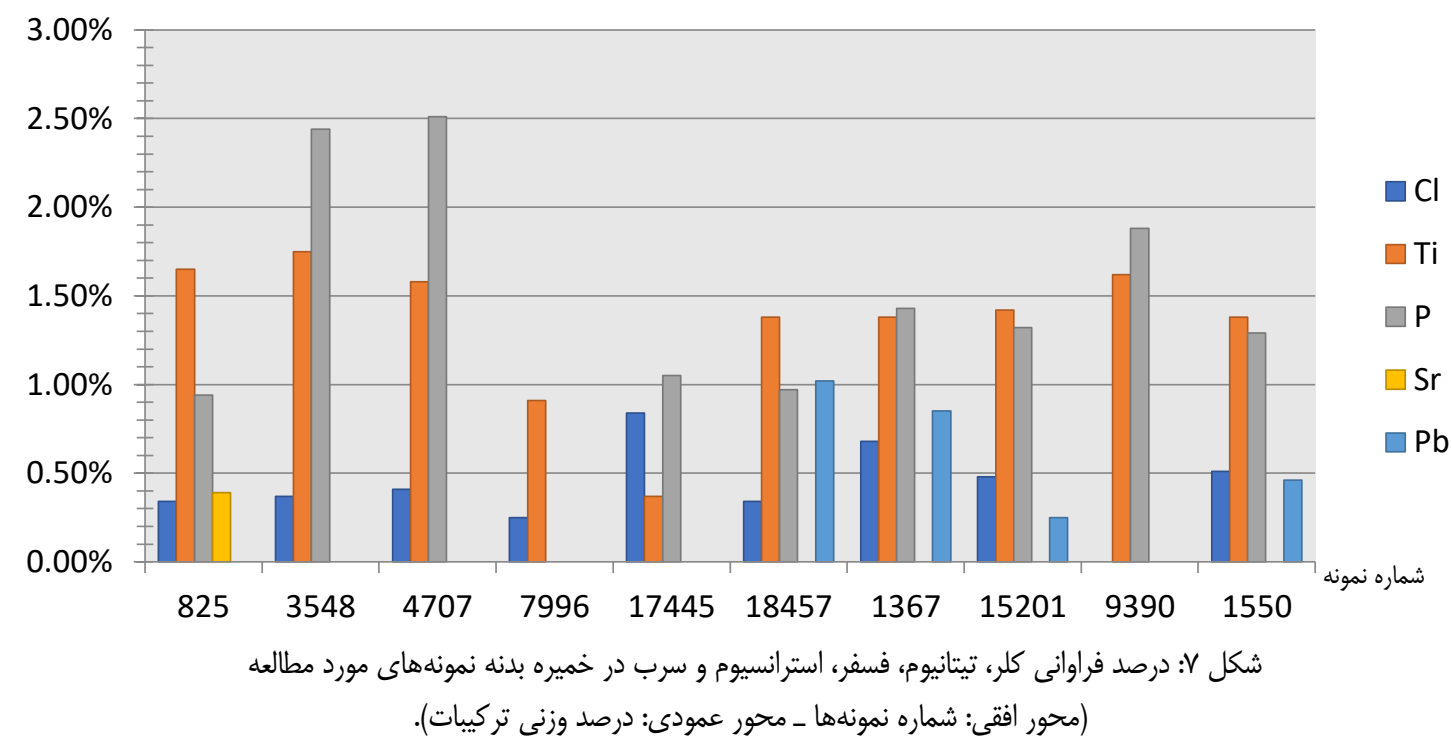

Fig. 7: The weight percentage (Wt.\%) Cl, TiO2, P2O5, SrO, PbO in the paste of the samples

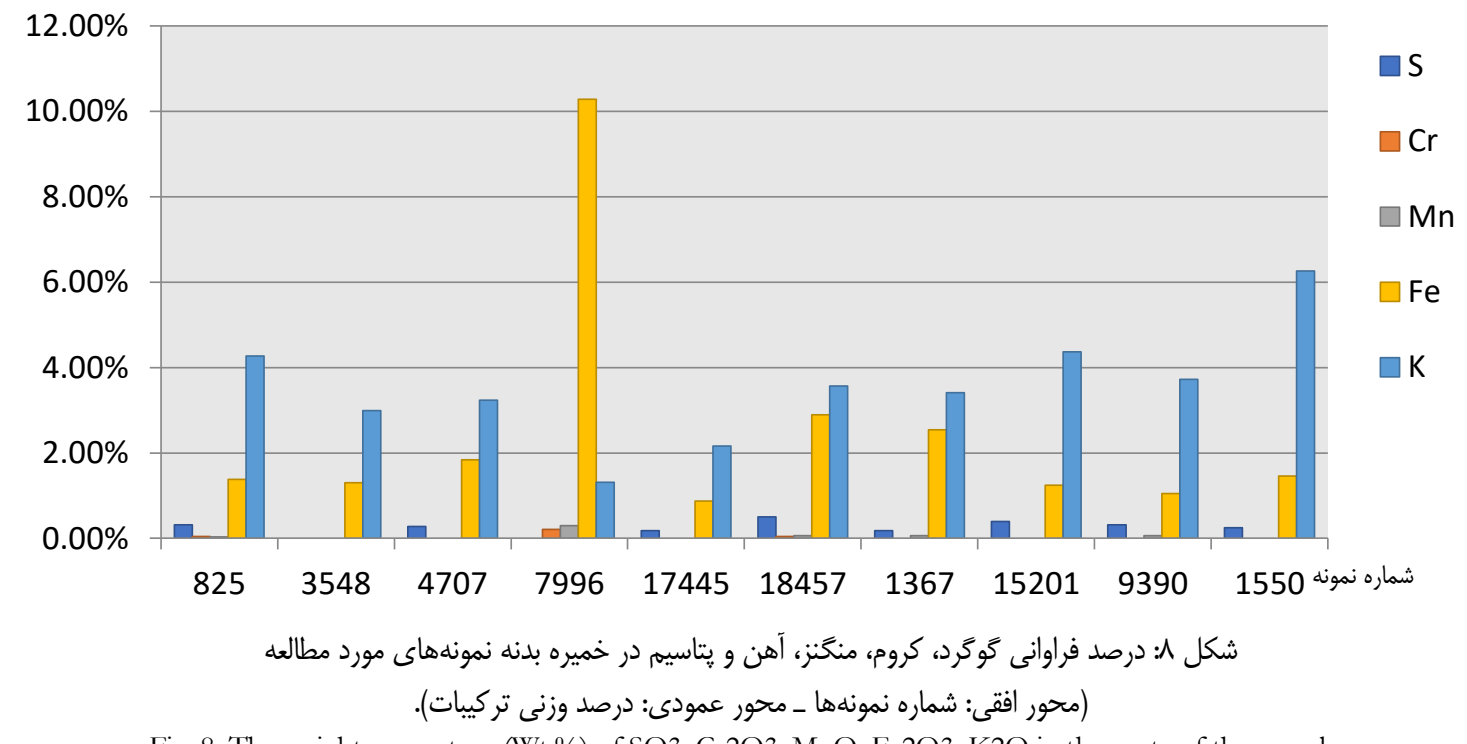

Fig. 8: The weight percentage (Wt.\%) of SO3, Cr2O3, MnO, Fe2O3, $\mathrm{K} 2 \mathrm{O}$ in the paste of the samples

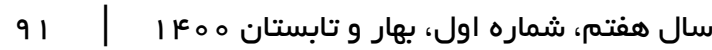


وجود دارد. براى بررسى بهتر و دقت در نتايج، آناليزهـا

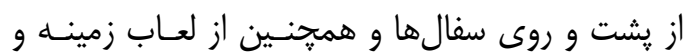

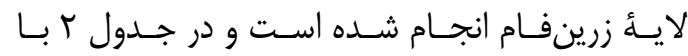

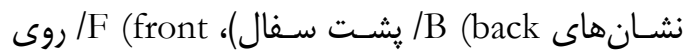

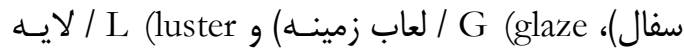
زرينفام) نام خذارى شده اسـت. رنـــ لعـاب زمينـهـ در

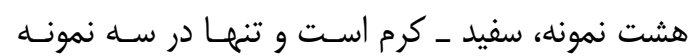

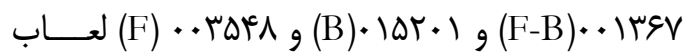

$$
\text { زمينٔة آبى نيز ديده مىشود. }
$$

\section{ع-r. نتايج آناليز لعاب زمينه و لايئ زرينفام}

در اين يزوهش، با جداسازى بخشهايى از هر نمونه در

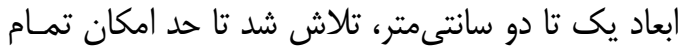
رنحهاى لعاب زمينه و لائُ زرينفام در هر نمونه آناليز شود. در جدول تركيبات عنصرى لعـاب زمينـه و لايـــ زرينفام (جدول ب)، علاوه بر عناصـر سـديم، منيـزيم، آلومينيوم، سيليسيه، فسفر، كوَّرد، كلر، يتاسيه، كلسيه،

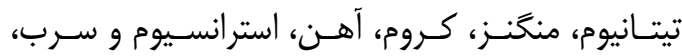
عناصرى ديكر مانند، مس، روى، كبالت، نقره و قلع نيز

جدول س: نتايج آزمايش لعاب و لايههاى زرينفام نمونهاى مورد مطالعه با روش ميكروبيكسى

Table 3: The results of the analysis of lustre and other glaze layers in the samples by Micro-PIXE

\begin{tabular}{|c|c|c|c|c|c|c|c|c|c|c|c|c|c|c|c|c|c|c|c|c|c|c|}
\hline sample & Color & G/L & $\mathrm{Na}$ & $\mathbf{M g}$ & Al & $\mathrm{Si}$ & $\mathbf{P}$ & S & $\mathrm{Cl}$ & K & $\mathrm{Ca}$ & $\mathrm{Ti}$ & $\mathbf{M n}$ & $\mathrm{Cr}$ & $\mathrm{Fe}$ & $\mathrm{Cu}$ & $\mathrm{Zn}$ & Co & $\mathrm{Ag}$ & Sn & $\mathbf{P b}$ & Sr \\
\hline 000825-B & Cream & G & 7.42 & 2.51 & 4.64 & 58.19 & \begin{tabular}{|l|}
1.44 \\
\end{tabular} & \begin{tabular}{|l|}
0.34 \\
\end{tabular} & 0.97 & 5.74 & 12.10 & 0.64 & 0.10 & 0.04 & 2.14 & 0.06 & 0.07 & nd & nd & 0.91 & 2.18 & 0.21 \\
\hline 000825-F & Cream & G & 7.33 & 1.28 & 2.17 & 35.41 & nd & nd & 1.07 & 2.06 & \begin{tabular}{|l|}
3.25 \\
\end{tabular} & 0.09 & nd & nd & 1.00 & 0.06 & nd & nd & nd & 10.46 & 35.15 & nd \\
\hline $000825-\mathrm{F}$ & \begin{tabular}{|l|} 
Olive \\
\end{tabular} & $\mathrm{L}$ & 3.24 & 1.46 & 2.25 & 37.02 & nd & nd & 0.79 & 3.11 & 3.42 & 0.07 & 0.03 & nd & 1.08 & 3.32 & nd & nd & 2.06 & \begin{tabular}{|l|l|}
5.78 \\
\end{tabular} & 36.22 & nd \\
\hline 003548-B & Cream & G & 8.01 & 2.42 & 4.90 & 62.55 & $\mid$\begin{tabular}{|l|}
1.61 \\
\end{tabular} & nd & 0.54 & 4.13 & 8.53 & 0.72 & 0.08 & nd & 1.99 & 0.13 & 0.06 & nd & nd & 1.00 & 2.53 & nd \\
\hline $003548-\mathrm{F}$ & Cream & G & 10.00 & 2.30 & 2.97 & 40.70 & nd & nd & 0.36 & 2.27 & 8.06 & nd & nd & nd & 1.65 & nd & nd & nd & nd & 11.40 & 18.31 & nd \\
\hline $003548-\mathrm{F}$ & Olive & $\mathrm{L}$ & 5.03 & 2.10 & 2.81 & 42.24 & 0.47 & nd & 0.49 & 3.60 & 8.65 & 0.18 & 0.08 & nd & 1.61 & 2.20 & nd & nd & 1.57 & 11.75 & 17.00 & nd \\
\hline 004707-B & Cream & G & 6.16 & 1.47 & 2.43 & 55.60 & 1.05 & nd & 0.46 & 3.45 & 3.86 & 0.11 & 0.03 & nd & 1.05 & 0.08 & nd & nd & nd & 5.24 & 16.25 & nd \\
\hline $004707-\mathrm{F}$ & Cream & G & 6.35 & 1.11 & 2.26 & 45.12 & nd & nd & 1.00 & 3.38 & 3.30 & 0.08 & 0.04 & nd & 0.96 & 0.20 & nd & nd & nd & 6.08 & 29.54 & nd \\
\hline 004707-F & Red & $\mathrm{L}$ & 5.75 & 0.98 & 2.10 & 44.83 & nd & nd & 0.66 & 3.01 & 3.22 & nd & nd & nd & 0.94 & 1.10 & nd & nd & 0.71 & 5.95 & 30.02 & nd \\
\hline 007996-B & \multicolumn{22}{|c|}{ ame color and form, so we did not any analysis from back glaze. } \\
\hline 007996-F & Cream & G & 3.32 & 2.14 & 2.74 & 45.88 & nd & nd & 0.31 & 6.24 & 5.39 & 0.11 & 0.18 & nd & 0.73 & 0.11 & nd & nd & nd & 10.44 & 21.21 & nd \\
\hline 007996-F & Olive & $\mathrm{L}$ & 2.32 & 1.99 & 2.51 & 45.89 & nd & nd & 0.50 & 6.46 & 5.29 & 0.10 & 0.17 & nd & 0.71 & 0.16 & nd & nd & 2.96 & 10.03 & 20.77 & nd \\
\hline 017445-B & Cream & G & 4.42 & 1.43 & 2.81 & 73.14 & \begin{tabular}{|l|l|}
0.84 \\
\end{tabular} & \begin{tabular}{|l|}
0.19 \\
\end{tabular} & 2.02 & 4.83 & 7.52 & 0.19 & 0.08 & 0.14 & 1.56 & 0.11 & nd & nd & nd & nd & nd & nd \\
\hline $017445-\mathrm{F}$ & Cream & $\mathrm{G}$ & 11.85 & 2.69 & 2.83 & 65.29 & 1.37 & 0.44 & 0.47 & 3.06 & 7.87 & 0.26 & nd & nd & 1.20 & 0.42 & nd & nd & nd & nd & nd & nd \\
\hline 017445-F & $\begin{array}{c}\text { Light } \\
\text { brown }\end{array}$ & $\mathrm{L}$ & 11.31 & 2.96 & 2.66 & 62.64 & 1.06 & 0.30 & 0.43 & 2.83 & 7.17 & 0.17 & 0.05 & nd & 1.04 & 7.12 & nd & nd & nd & nd & nd & nd \\
\hline 018457-B & Cream & G & 4.01 & 2.01 & 8.65 & 51.83 & \begin{tabular}{|l|l}
0.97 \\
\end{tabular} & \begin{tabular}{|c|}
0.85 \\
\end{tabular} & 1.79 & 6.19 & 8.94 & 0.98 & 0.07 & 0.04 & 3.33 & 0.17 & 0.10 & nd & nd & 1.46 & 8.18 & nd \\
\hline $018457-\mathrm{F}$ & Cream & $\mathrm{G}$ & 6.49 & 1.69 & 2.58 & 39.37 & nd & nd & 0.90 & 2.36 & 6.42 & 0.10 & nd & nd & 0.98 & 0.32 & nd & nd & nd & 7.02 & 31.35 & nd \\
\hline 018457-F & $\begin{array}{c}\text { Light } \\
\text { brown }\end{array}$ & $\mathrm{L}$ & 4.48 & 1.39 & 2.51 & 38.31 & nd & nd & 0.74 & 2.44 & 6.59 & 0.08 & 0.03 & nd & 0.92 & 2.24 & nd & nd & 1.56 & 6.52 & 31.92 & nd \\
\hline $001367-B$ & Cream & G & 8.10 & 1.39 & 2.87 & 39.40 & nd & nd & \begin{tabular}{|l|l|}
1.77 \\
\end{tabular} & 2.53 & 4.15 & 0.20 & nd & nd & 0.76 & 0.08 & nd & nd & nd & 7.45 & 30.72 & nd \\
\hline $001367-\mathrm{F}$ & Cream & G & 5.71 & 1.42 & 1.82 & 42.58 & nd & nd & 0.69 & 4.43 & 3.77 & 0.06 & 0.03 & 0.04 & 0.70 & 0.14 & nd & nd & nd & 5.49 & 32.81 & nd \\
\hline $001367-\mathrm{F}$ & Brown & $\mathrm{L}$ & 4.93 & 1.17 & 1.49 & 41.71 & nd & nd & 0.59 & 4.69 & 3.80 & 0.07 & 0.02 & nd & 0.70 & 0.52 & nd & nd & 0.90 & 5.51 & 33.59 & nd \\
\hline $001367-\mathrm{F}$ & \begin{tabular}{|l|} 
Blue \\
\end{tabular} & G & 5.39 & 1.57 & 2.27 & 42.76 & nd & nd & 0.79 & 4.71 & 4.70 & 0.08 & 0.06 & nd & 0.89 & 0.13 & nd & 0.09 & nd & 4.90 & 31.25 & nd \\
\hline 015201-B & Blue & $\mathrm{G}$ & 7.85 & 2.06 & 2.47 & 64.61 & 0.74 & 0.17 & 0.48 & 6.06 & 7.68 & 0.22 & 0.12 & nd & 3.98 & 0.37 & nd & 0.32 & nd & nd & 2.50 & nd \\
\hline 015201-F & Cream & G & 14.39 & 2.96 & 3.42 & 55.23 & \begin{tabular}{|l|l}
0.87 \\
\end{tabular} & nd & \begin{tabular}{|l|l|}
1.47 \\
\end{tabular} & 4.62 & 7.11 & 0.14 & 0.04 & 0.06 & 1.67 & 0.04 & nd & nd & nd & 1.65 & 5.89 & nd \\
\hline 015201-F & Brown & $\mathrm{L}$ & 6.51 & 2.45 & 2.23 & 56.05 & \begin{tabular}{|l|}
0.47 \\
\end{tabular} & \begin{tabular}{|l|}
0.32 \\
\end{tabular} & $\mid 0.49$ & 5.21 & 7.36 & 0.13 & 0.05 & nd & 1.66 & 6.55 & nd & nd & 3.17 & nd & 7.12 & nd \\
\hline 009390-B & \multicolumn{22}{|c|}{ Without any glaze, so it did not analyzed } \\
\hline 009390-F & eam & G & 7.49 & 3.01 & 2.54 & 62.76 & 0.96 & nd & 0.59 & 5.85 & 6.48 & 0.13 & nd & nd & 2.32 & 0.87 & nd & nd & nd & nd & 5.55 & nd \\
\hline 009390-F & Brown & $\mathrm{L}$ & 5.96 & 2.74 & 2.14 & 60.45 & nd & nd & 0.54 & 5.78 & 6.64 & nd & 0.07 & nd & 2.36 & 4.22 & nd & nd & 1.68 & 1.46 & 5.40 & nd \\
\hline 001550-B & Cream & - & 5.85 & 2.04 & 6.69 & 45.90 & 0.41 & 0.21 & 1.20 & 4.98 & 7.64 & 0.59 & 0.07 & 0.03 & 1.55 & 0.27 & 0.03 & nd & nd & 5.85 & 16.39 & 0.17 \\
\hline 001550-F & Cream & $G$ & 5.64 & 1.69 & 1.64 & 40.03 & nd & nd & \begin{tabular}{|l|}
0.77 \\
\end{tabular} & 2.51 & 4.24 & 0.24 & nd & nd & 0.72 & 1.24 & nd & nd & nd & 10.16 & 30.28 & nd \\
\hline $001550-\mathrm{F}$ & Olive & $\mathrm{L}$ & 4.79 & 1.93 & 1.93 & 39.69 & nd & nd & $|0.77|$ & 2.39 & 4.09 & 0.18 & 0.03 & nd & 0.70 & 4.42 & \begin{tabular}{|l|}
0.03 \\
\end{tabular} & nd & 0.53 & 9.42 & 28.82 & nd \\
\hline $001550-\mathrm{F}$ & Brown & $\mathrm{L}$ & 5.54 & 2.01 & 2.08 & 40.99 & nd & nd & 0.72 & 2.56 & 4.35 & 0.17 & 0.05 & nd & 0.69 & 2.49 & nd & nd & 0.33 & 6.39 & 30.27 & nd \\
\hline
\end{tabular}

سيليس يا كوارتز در واقع قسمت اصلى لعاب يـا عامـل

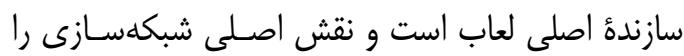

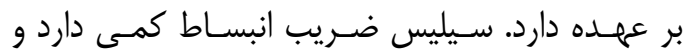

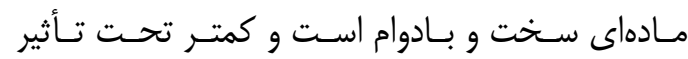

نتايج آناليز ميكروييكسى نشان مىدهد بيشترين ميزانِ

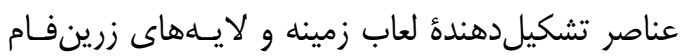
شامل سيليس، سرب، ســيه، آلومينيـوم و قلـع اسـت.

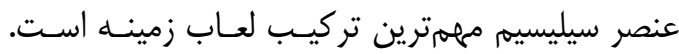


قلع و سيليس در بسيارى از نقاط ديخر هم در لعابهـا قابل مشاهده است.

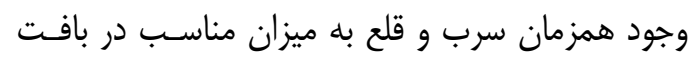
شيشهاى لعابها بـهـ عنـوان شبكهسـاز لعـاب و ايجـاد

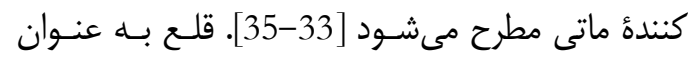

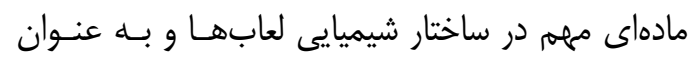
يك اثر انخشت زئوشيميايى اهميت دارد و كدر كنتـده و

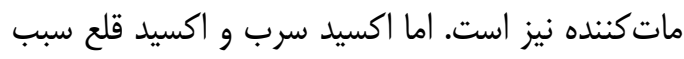

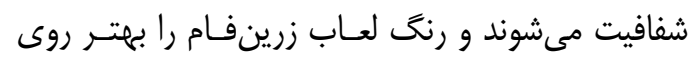
بدنأ سفالين بروز مىدهند [37]. عنصر سرب و قلع، به

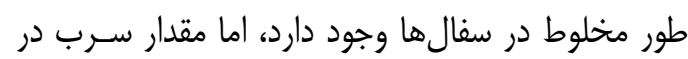
سفالها بيشتر است.

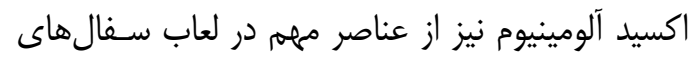

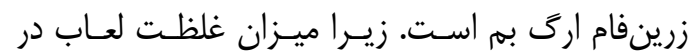

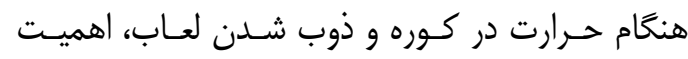
زيادى داشته و اين غلظت و روانى لعاب با اضافه كردن اكسيد آلومينيوم كنترل مى شده است. اكسيد آلومينيـوم

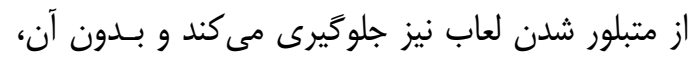

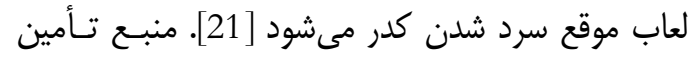

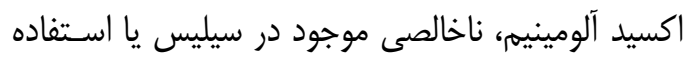
از موادى مانند كائولين است.

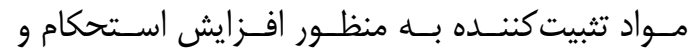

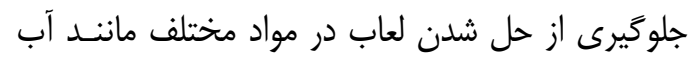
استفاده مىشده است. كربنات كلسيهم از رايجترين مواد

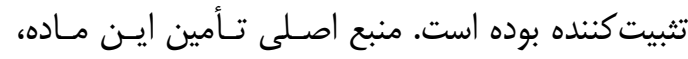

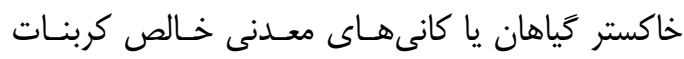

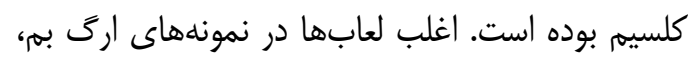
اكسيد كلسيم دارند و اين عنصر، در لعابها بـه عنـوان تثبيت كننده شبكه اصلى به كار مىرود. وجـود كلسـيم إنها

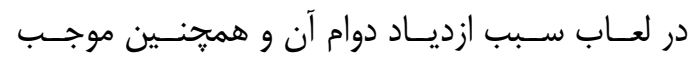

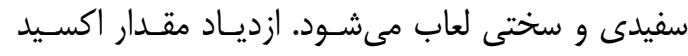

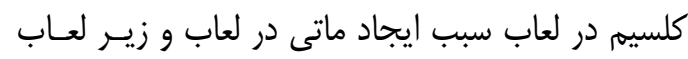

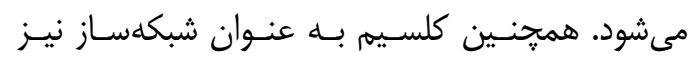
استفاده شده است [7].

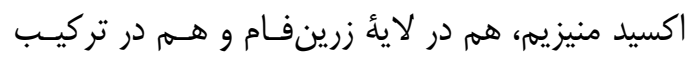

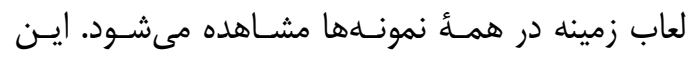
عنصر غالباً از طريق ناخالصىهاى موجـود در حَدازآور qu
تغييرات شيميايى قرار مى گيرد و همين خاصـيت آن را

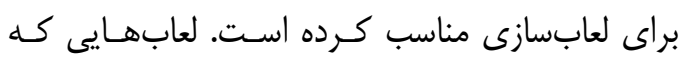
سيليس بيشترى دارند نسبت به لعابهايى كه سـيليس

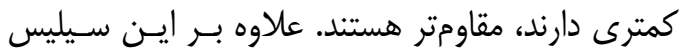

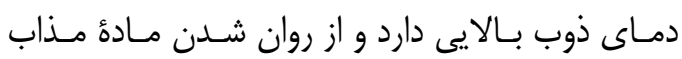

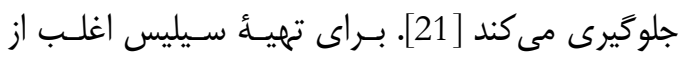

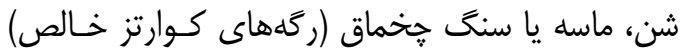

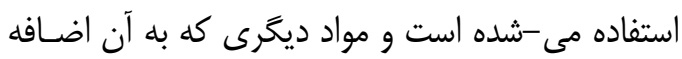

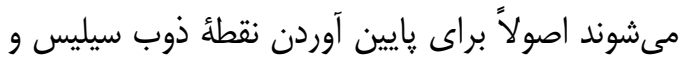

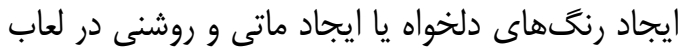

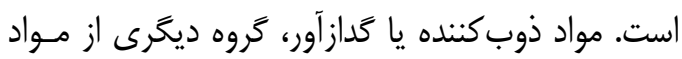

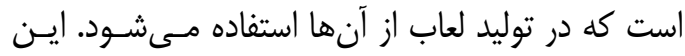

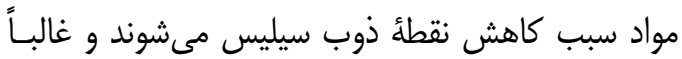

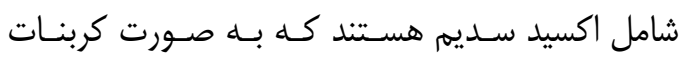
سديم، سولفات سديم، استات سديم مورد استفاده قـرار

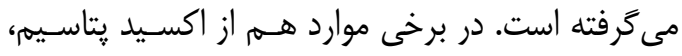

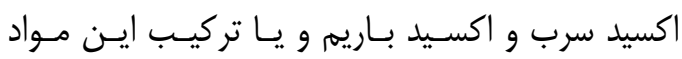

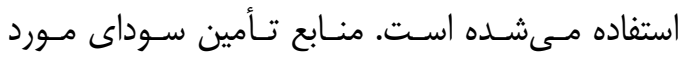

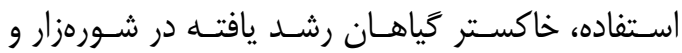

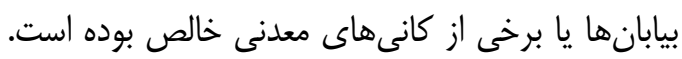

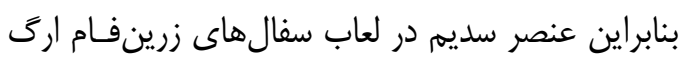
بم نقش مهمى را ايفا كرده است. زيرا در اين نمونسهها

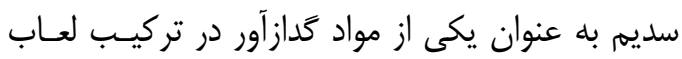

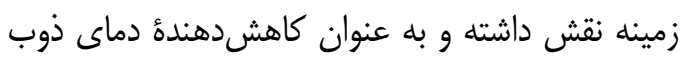

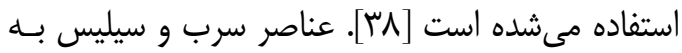

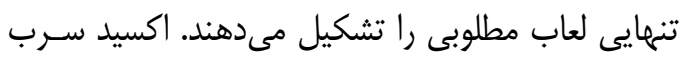

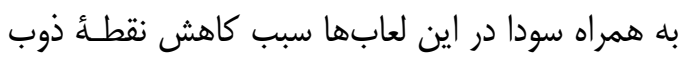
سيليس شده است. همجنـين، لعابهـايى كـه اكسـيد

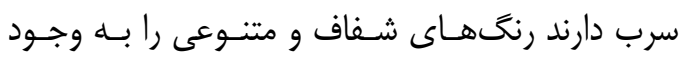
مى آورند. ضريب انبساط سرب كم و با بيشـتر سـفال هاريا ساز كار است. اكسيد سرب بايد در كورههايى كه داخـل

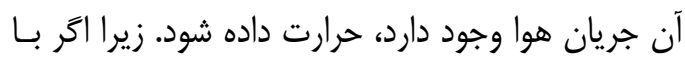

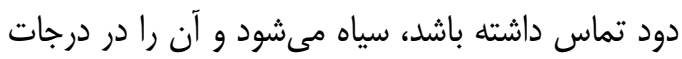

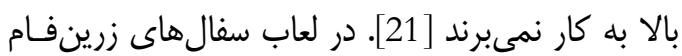

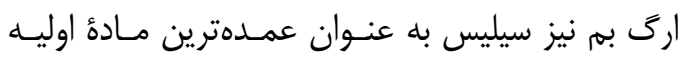

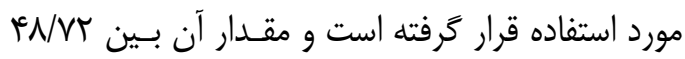

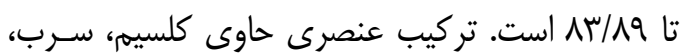


يتاسيم جزو تركيبات شيميايى است كه هم در سـاختار

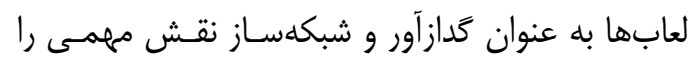
ايفا مى كند و هم در بدنه و لعاب سفالها سـبب ايجـاد

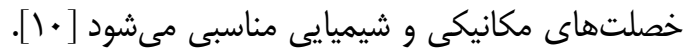

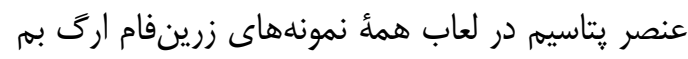

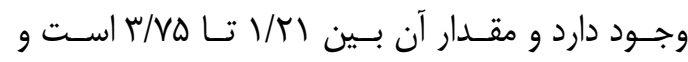
مىتواند نقش كدازآور نيز داشته باشد.

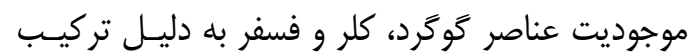

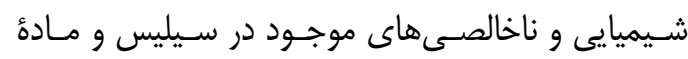

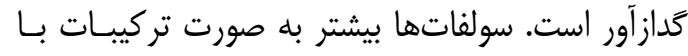

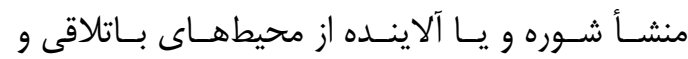

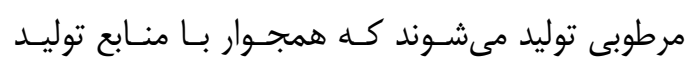

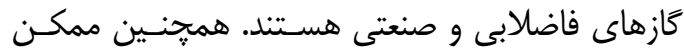

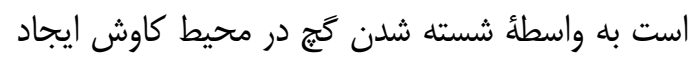

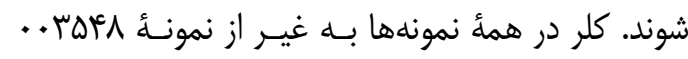

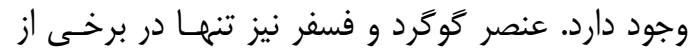
نمونهها مشاهده شد.

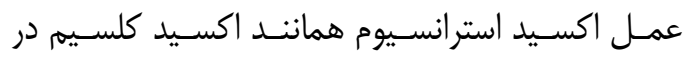

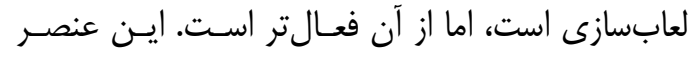

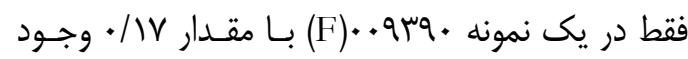

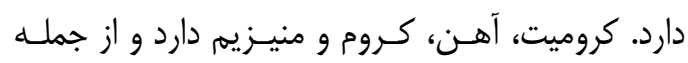

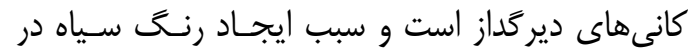

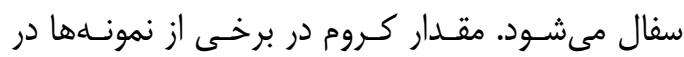
حدود ץ+/• تا זr/• درصد و بسيار كم است.

\section{ه. بحث؛ منشأ يابى سفالها}

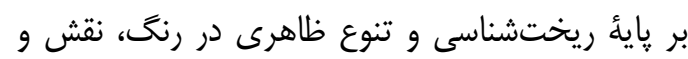

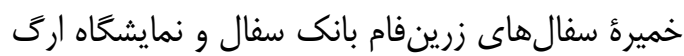
بم، ييش از انجام اين يُوهش اين كَونه به نظر

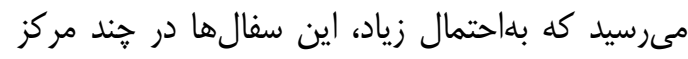

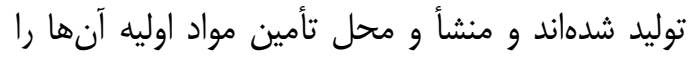
بايد در هند منطقه جستجو كرد. براى تأييد يا رد اين

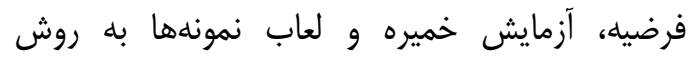

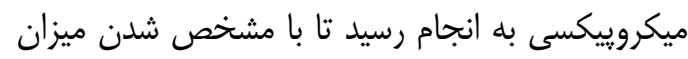

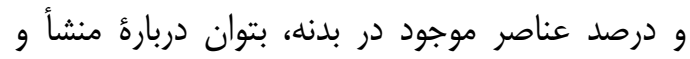

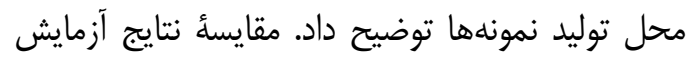

كه در اين نمونهها اكسيد سـديم يـا سـودا اسـت، وارد

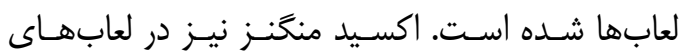

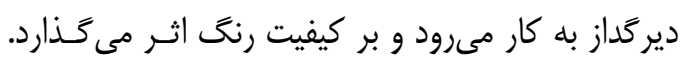

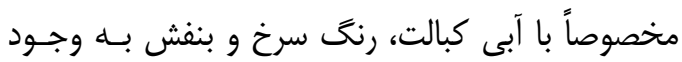

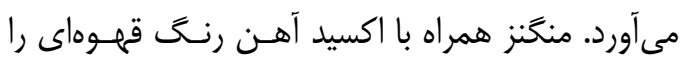
ايجاد مى كند [21]. اكسيد مس در لعابهاى قليايى، به عنوان مادهٔ رنخزا و

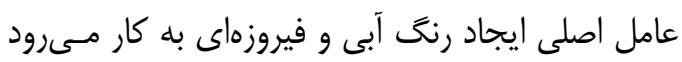

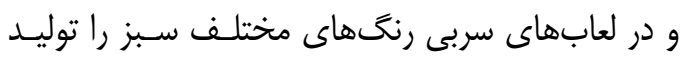

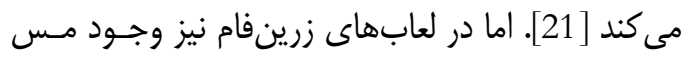
در كنار نقره، سبب ايجاد طيفهاى رنكى مختلف لائُ

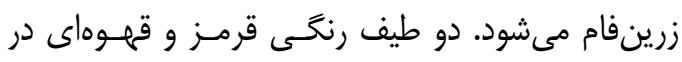

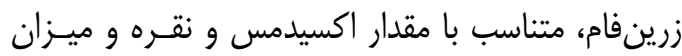

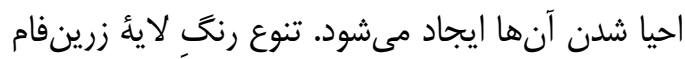

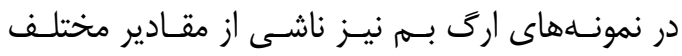
اكسيدمس و نقره است.

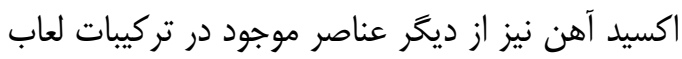

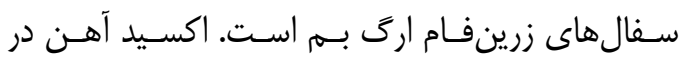

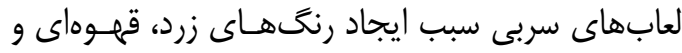

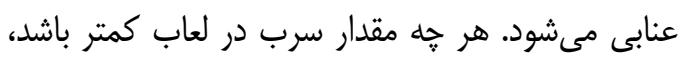

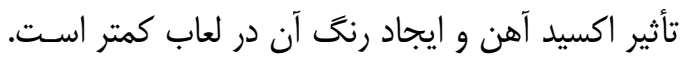

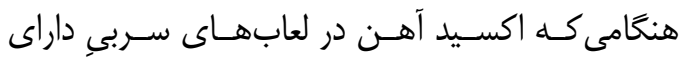

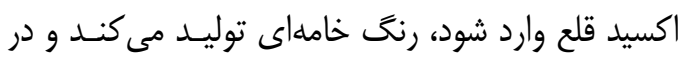

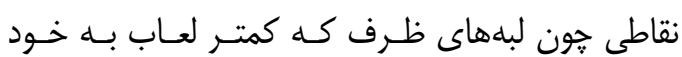

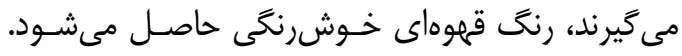

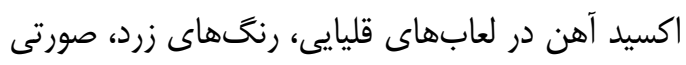

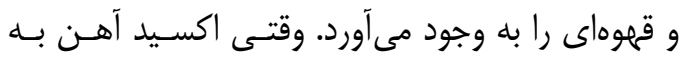
لعابهاى داراى اكسيد روى افزوده شود، رنغ به دست اله

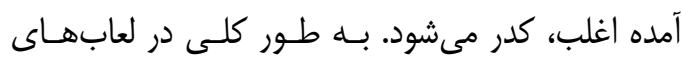
بدون اكسيد روى، بهترين نتيجه با افزودن اكسيد آهن حاصل مىشود [21]. اكسيد كبالت به عنوان مادهُ يديد آورندهُ رنحَ آبى، تنها

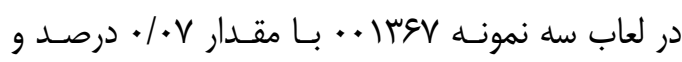

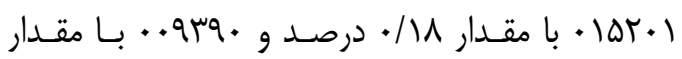

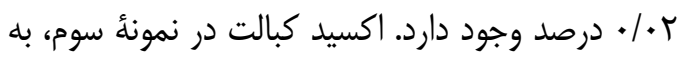

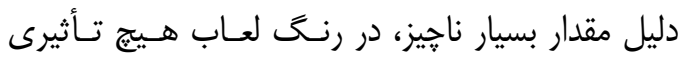
نخذاشته است. 
متفاوتى باشند. به بيان ديخر، بر اساس آناليزهاى فوق،

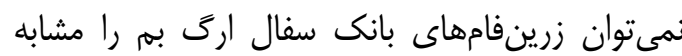

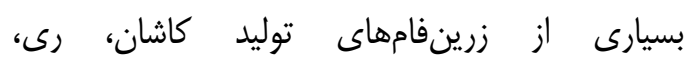

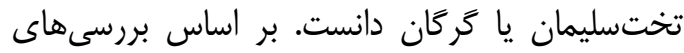
زمينشناسى، كانى منيزيم در خاك نواحى كرمان شناسايى شده است. براى نمونه، درّه آشين در اطر نوافي جيرفت از نظر غناى منيزيم در تركيبات خاك مورد توجه است. وجود منيزيم در كاشىهاى زرينفام قدام

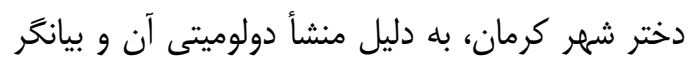
اين است كه معادن خاك مورد استفاده براى ساخت بدنه سفال از لحاظ زمينشناسى، منطقهاى متامورفيكى إنى

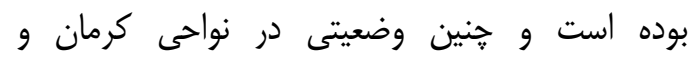
شهرهاى ييرامون آن وجود دارد [37]. از سوى دينئر،

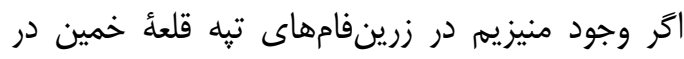

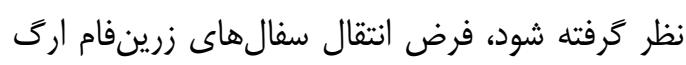
بم از منطقهاى مانند خمين به بهم، فرضى بعيد است.

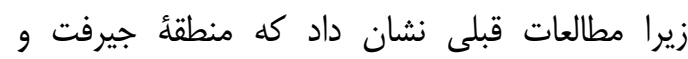

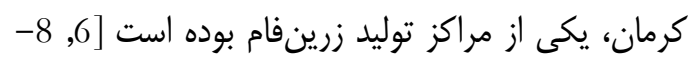

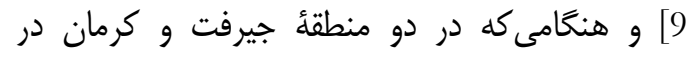

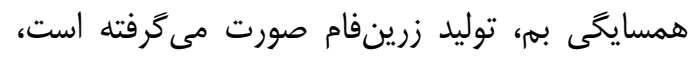

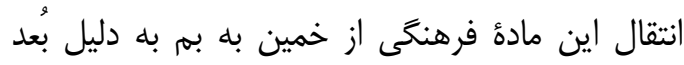
مسافت منطقى نيست. اين موضوع، در تبيين و توضيح بومى بودن توليد سفال هاى زرين فام اركى به ـ همانند كاشىهاى زرينفام قلعه دختر شهر كرمان و سفالهاى نوري

زرينفام جيرفت ـ اهميت بسيارى دارد.

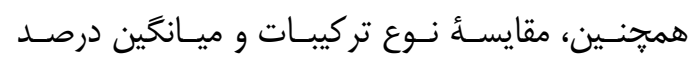

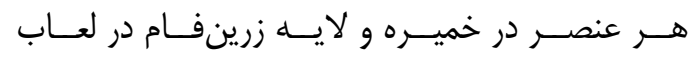

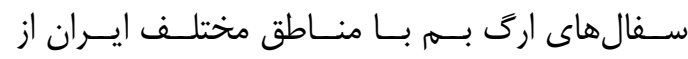

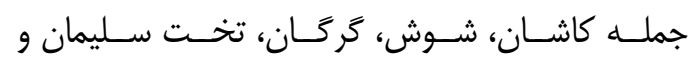

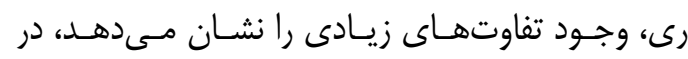

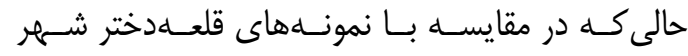

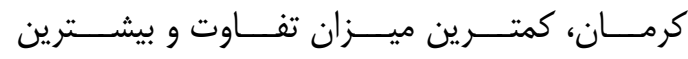

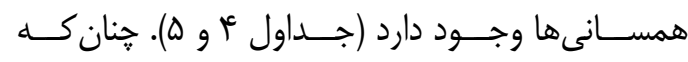

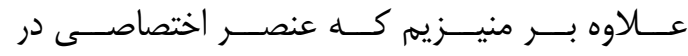

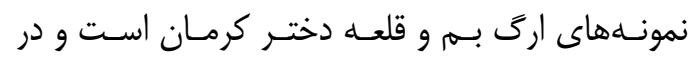

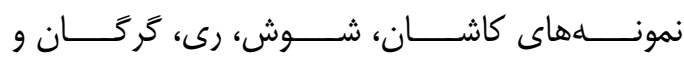

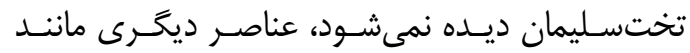

ميكروييكسى با دادههاى يزوهشهاى ييشين دربارة

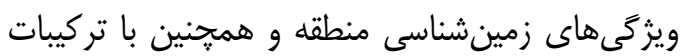
عنصرى سفالهاى زرينفام نواحى ديخر ايران، ابهامات موجود رادر اينباره زدود. اميرحاجلو و همكاران در مطالعأ كاشىهاى زرينات زوردان كاوش شده از قلعهدختر شهر كرمان و مقايسٔ تركيبات عنصرى نمونههاى كاشى قلعهدختر با نمونهاي

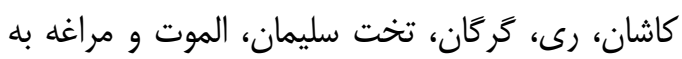

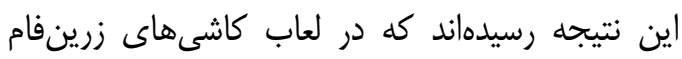
قلعهدختر شهر كرمان، مقاديرى از منيزيم وجود دارد

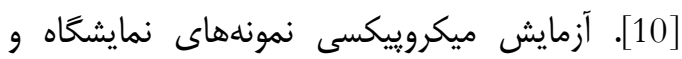

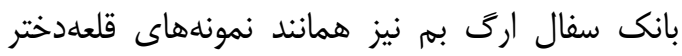
شهر كرمان، نشان مىدهد كه منيزيم در تركيب عنصرى سفالها وجود دارد. در حالى كه در تمان مطالعاتى كه در بخش ييشينأ يزوهش به به آنها اشاره

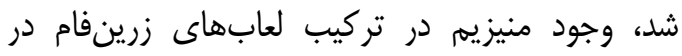

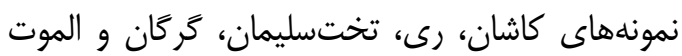
كزارش نشده است و تنها يكى استثناء در اين زمينه وجود دارد كه آن هم نمونههاى زرينفام مجموعأ

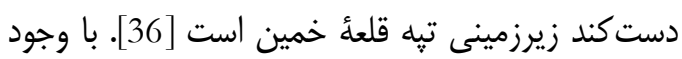

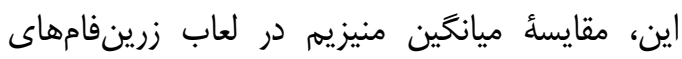

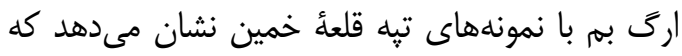
منيزيم در زرينفامهاى خمين به ميزان كمترى وجود

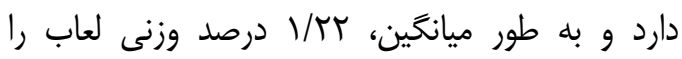

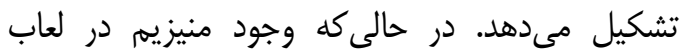

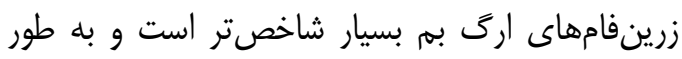

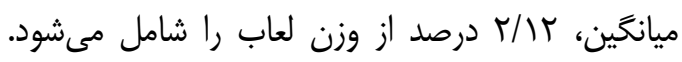

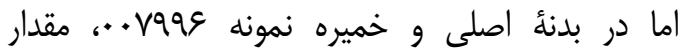
منيزيم بسيار بالاتر از ديخر نمونهها است و اين نمانه نمانه

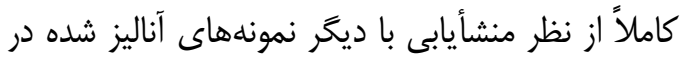
اين يزوهش متفاوت است. از طرفى منيزيم موجود در

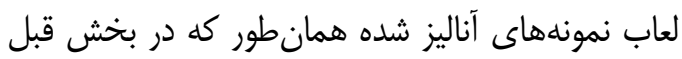
نيز اشاره شد، مىتواند ناشى از ناخالصى موجود در ماده

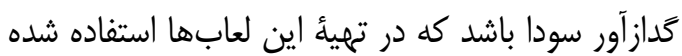

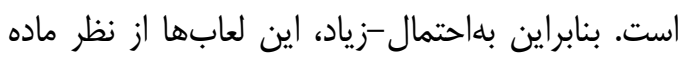
اوليه، با لعاب زرينفامهاى كاشان، رى و تختسليمان متفاوت هستند و مىتوانند نشاندهندهُ محل ساخت 
حالى كسه در نمونسههاى ارگ بـم و قلعـه دختــر شـمر

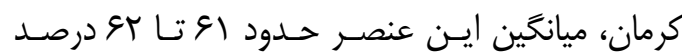

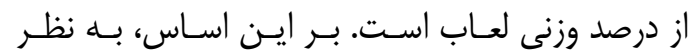

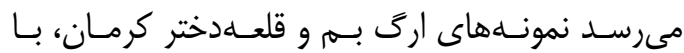

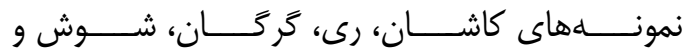
تختسليمان از نظر منشأ متفاوت هستند.
فسـفر، سـديم و خـوخرد در تركيـب لعـاب نمونـههاى

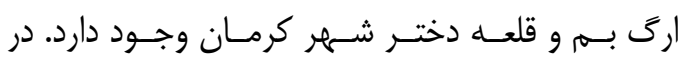

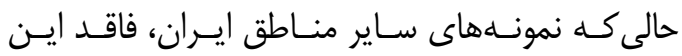

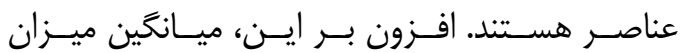

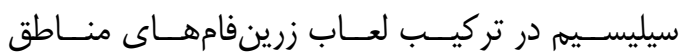

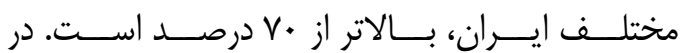

جدول f: ميانكين ميزان عناصر در لايه زرينفام در لعاب سفالهاى اركى بم و ديكر مناطق ايران

Table 4: The average amount of elements in the glaze of the lustrewares of Arg-e Bam and other sites of Iran

\begin{tabular}{|c|c|c|c|c|c|c|c|c|c|c|c|c|c|c|c|c|c|c|c|}
\hline Site & $\begin{array}{c}\text { Number } \\
\text { of } \\
\text { Samples }\end{array}$ & $\mathbf{N a}$ & $\mathbf{M g}$ & $\mathbf{S i}$ & $\mathbf{P}$ & $\mathbf{S}$ & $\mathbf{C l}$ & $\mathbf{K}$ & $\mathbf{C a}$ & $\mathbf{T i}$ & $\mathbf{M n}$ & $\mathbf{C r}$ & $\mathbf{F e}$ & $\mathbf{C u}$ & $\mathbf{Z n}$ & $\mathbf{A g}$ & $\mathbf{S n}$ & $\mathbf{P b}$ & $\mathbf{S r}$ \\
\hline Bam & 10 & 5.44 & 1.92 & 46.34 & 0.18 & 0.05 & 0.61 & 3.82 & 5.50 & 0.10 & 0.05 & 0 & 1.12 & 3.12 & 0 & 1.40 & 5.71 & 21.92 & 0 \\
\hline $\begin{array}{c}\text { Qal'eh } \\
\text { Dokhtar } \\
\text { Kerman }\end{array}$ & 11 & 1.17 & 1.40 & 61.60 & 0.42 & 0.19 & 0.18 & 3.25 & 3.29 & 0.06 & 0.01 & 0 & 0.61 & 0.80 & 0 & 1.15 & 5.29 & 17.26 & 0 \\
\hline Kashan & 7 & 0 & 0 & 70.99 & 0 & 0 & 1.60 & 1.85 & 2.17 & 0.06 & 0.01 & 0 & 0.48 & 1.07 & 0 & 0.70 & 3.87 & 18.97 & 0 \\
\hline Susa & 3 & 0 & 0 & 81.15 & 0 & 12.40 & 1.58 & 2.98 & 2.65 & 0.09 & 0.68 & 0.01 & 0.77 & 0.60 & 0.03 & 1.66 & 1.81 & 3.61 & 0 \\
\hline Gorgan & 4 & 0 & 0 & 70.92 & 0 & 0 & 1.62 & 2.15 & 2.8 & 0.07 & 0.03 & 0 & 0.62 & 1.09 & 0 & 0.39 & 5.00 & 16.27 & 0 \\
\hline Reyy & 9 & 0 & 0 & 70.82 & 0 & 0 & 0.72 & 1.95 & 1.99 & 0.09 & 0.01 & 0 & 0.57 & 1.18 & 0.01 & 0.72 & 3.85 & 16.73 & 0 \\
\hline $\begin{array}{c}\text { Takh-e } \\
\text { Soleyman }\end{array}$ & 5 & 0 & 0 & 71.47 & 0 & 0 & 0.37 & 1.54 & 2.64 & 0.05 & 0.01 & 0 & 0.90 & 0.84 & 0 & 0.23 & 4.02 & 15.66 & 0 \\
\hline
\end{tabular}

جدول ه: ميانكين ميزان عناصر در خميره بدنهُ زرينفامهاى اركَ بمه ديكر مناطق ايران

Table 5: The average amount of the elements in the paste of the lustrewares of Arg-e Bam and other sites of Iran

\begin{tabular}{|c|c|c|c|c|c|c|c|c|c|c|c|c|c|c|c|c|c|c|}
\hline Site & $\begin{array}{c}\text { Number } \\
\text { of } \\
\text { Samples }\end{array}$ & $\mathbf{N a}$ & $\mathbf{M g}$ & $\mathbf{A l}$ & $\mathbf{S i}$ & $\mathbf{P}$ & $\mathbf{S}$ & $\mathbf{C l}$ & $\mathbf{K}$ & $\mathbf{C a}$ & $\mathbf{T i}$ & $\mathbf{M n}$ & $\mathbf{F e}$ & $\mathbf{S r}$ & $\mathbf{P b}$ & $\mathbf{C r}$ & $\mathbf{N i}$ & $\mathbf{A s}$ \\
\hline Bam & 10 & 4.64 & 1.78 & 8.24 & 68.93 & 1.38 & 0.24 & 0.42 & 3.54 & 4.01 & 1.34 & 0.05 & 1.61 & 0.03 & 0.25 & 0.02 & 0 & 0 \\
\hline $\begin{array}{c}\text { Qal'eh } \\
\text { Dokhtar } \\
\text { Kerman }\end{array}$ & 11 & 1.93 & 5.31 & 14.24 & 56.14 & 0.76 & 0.56 & 0.90 & 1.52 & 14.66 & 0.59 & 0.06 & 4.02 & 0 & 0.18 & 0 & 0 & 0 \\
\hline Kashan & 7 & 0 & 0 & 5.83 & 90.63 & 0 & 0 & 0.83 & 1.92 & 1.88 & 0.5 & 0.02 & 1.07 & 0 & 0.79 & 0 & 0.2 & 0 \\
\hline Susa & 3 & 0 & 0 & $ن$ & 66.67 & 0 & 0 & 0 & 0.98 & 15.25 & 0.37 & 0.10 & 4.18 & 0 & 0 & 0.03 & 0 & 0 \\
\hline Gorgan & 4 & 0 & 0 & 8.05 & 82.7 & 0 & 0 & 0.84 & 1.61 & 5.12 & 0.59 & 0.05 & 2.12 & 0 & 0.2 & 0.04 & 0 & 0.1 \\
\hline $\begin{array}{c}\text { Takh-e } \\
\text { Soleyman }\end{array}$ & 5 & 0 & 0 & 10.06 & 85.49 & 0 & 0 & 0.82 & 0.82 & 2.16 & 0.49 & 0.01 & 0.50 & 0 & 0.30 & 0 & 0 & 0 \\
\hline Reyy & 9 & 0 & 0 & 8.68 & 87.05 & 0 & 0 & 0.76 & 1.19 & 1.35 & 0.31 & 0.23 & 0.54 & 0 & 0.72 & 0 & 0 & 0 \\
\hline
\end{tabular}

ديخر بايد از توليدات محلى و منطقهاى دانست. نخست

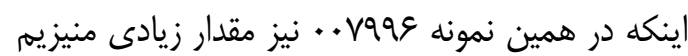

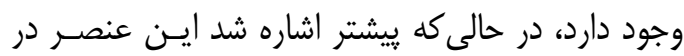

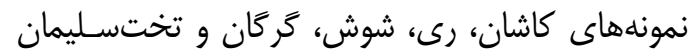

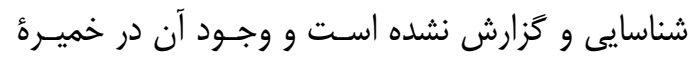

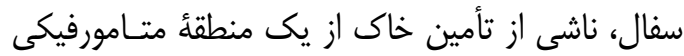

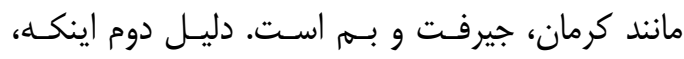

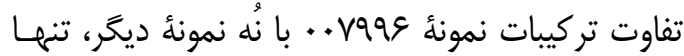

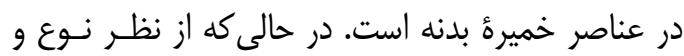

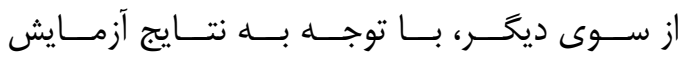

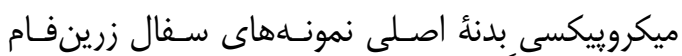

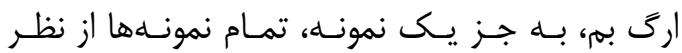

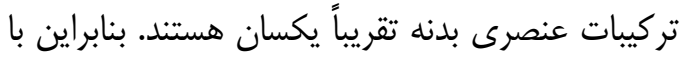

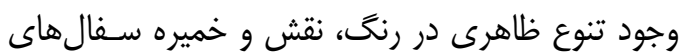

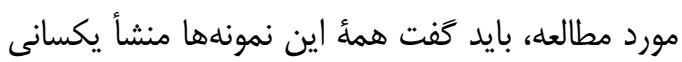

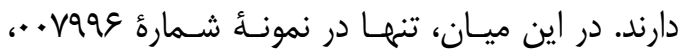

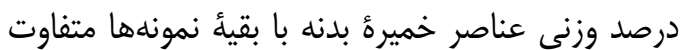

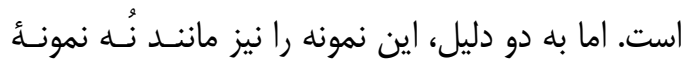


در نمونههاى بانك سفال و نمايشگاه ارك بم وجود

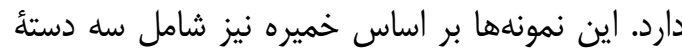

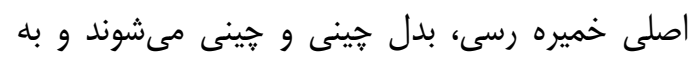

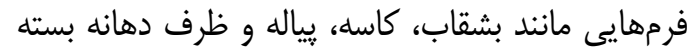

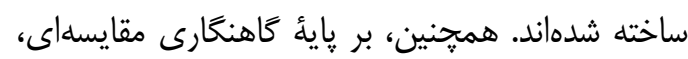

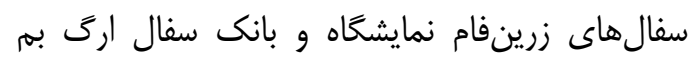

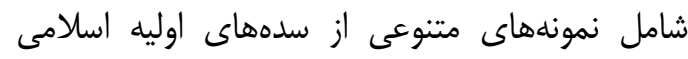

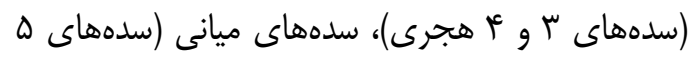

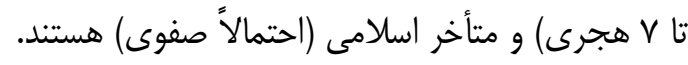

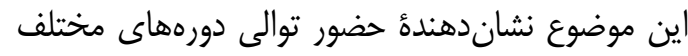
در سفالهاى حاصل از ارى قديم بم است.

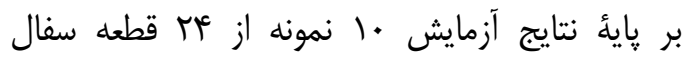

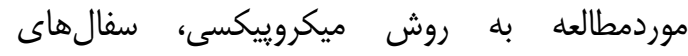
نمايشگاه و بانك سفال ارى بم نيز همانند نمونههاى

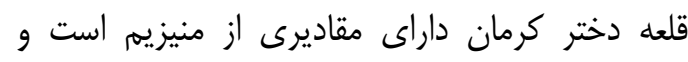

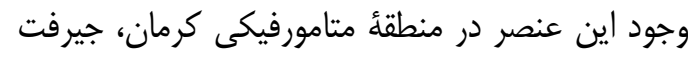
و بمم قطعى است. در حالى كه در نمونههاى زرينفام

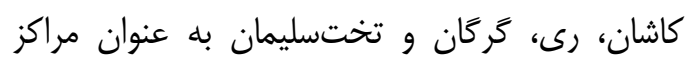

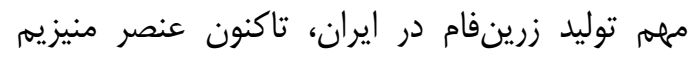
كزارش نشده است. افزون بر اين، عناصر ديخرى ماند ماند

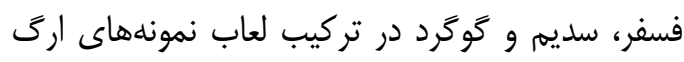

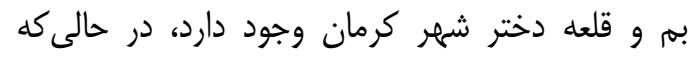
نمونههاى ساير مناطق ايران، فاقد اين عناصر هستند. بنابراين، به نظر مىرسد منشأ زرينفامهاى ارى مانى بهم،

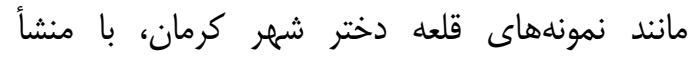

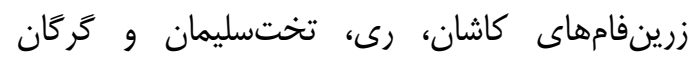
متفاوت است و بلاحتمالزياد، نمونههاى ارى بم بم مانند

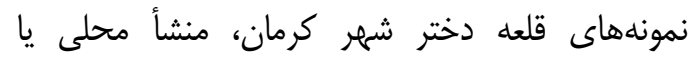

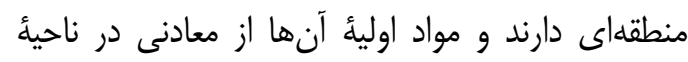

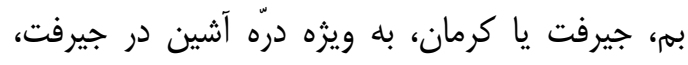

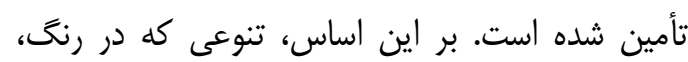
نقش و خميره زرينفامهاى بانك سفال و نمايشگاه

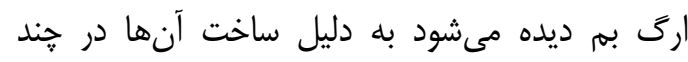
مركز توليد در نقاط مختلف ايران نبوده است، بلكه بها دانه

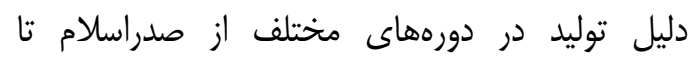

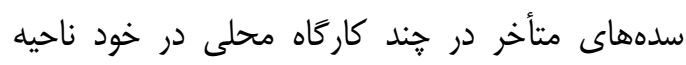
كرمان، بم و جيرفت بوده است.
درصد تركيبات لعاب، اين نمونه بانهُ نمونأه ديخر تفاوت

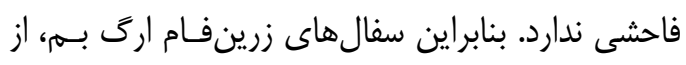

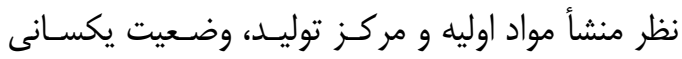

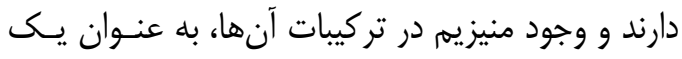
شاخصأ منحصربهفرد در ناحية كرمان، نشـانكر تـأمين

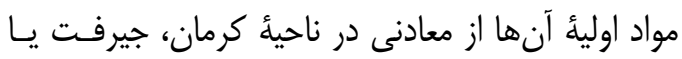

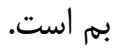
بر ايناساس، تنوعى كه در رنغ، نقش و خميره

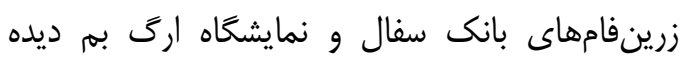

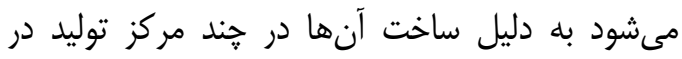
مناطق ديخر ايران نيست، بلكه به دليل توليد سفالها در دورههاى مختلف از صدراسلام تا سدههاى متأخر

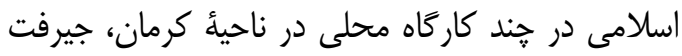

$$
\text { يا بهم است. }
$$

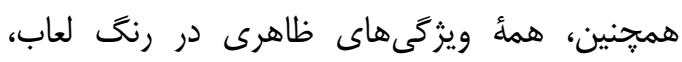
نقش و خميره سفالهاى زرينفام ارك بم را مى متوان

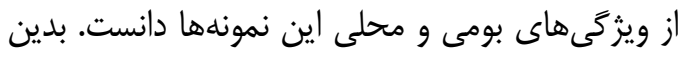

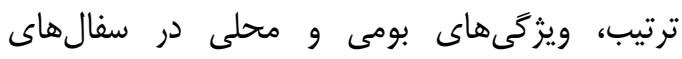

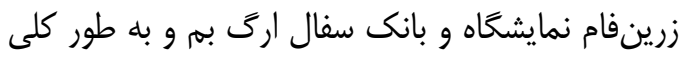
در صنعت سفال زرينفام كرمان شامل موارد زير است:

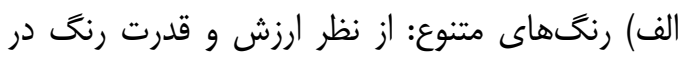
طيفى از روشن تا تيره و از نظر فام رنح در طيفى از

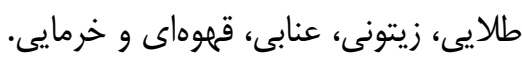

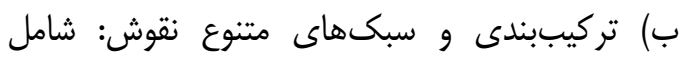
سبك درشتنقش و ريزنقش. ج) وجود تنوعى از نقوش انتزاعى، كَياهى رئاليستى و

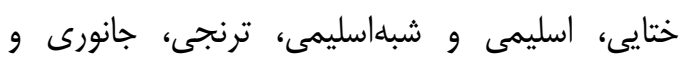
انسانى، هندسى، كتيبه نسخ و تعليق يا شبه كتيبه و ونيه

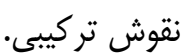

\section{7. - (نتيجه كيرى}

نتايج اين يزوهش نشان داد كه سفـالهاى زرين فئرى

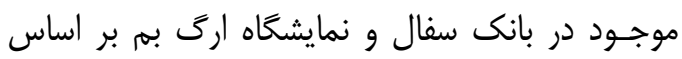
نقش، به دو نوع درشتنقش و ريزنقش تقسيهبندى

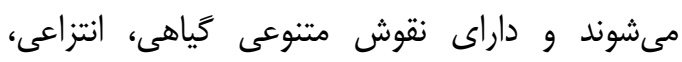

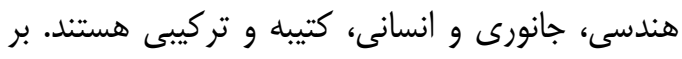
اساس رنغَ، همأ انواع رنحَهاى رايج در لائُ زرينفام 


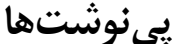

1. نمونهبردارى از قطعات زرينفام بانكى سفال و نمايشكاه

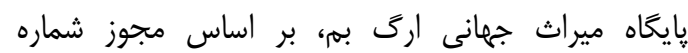

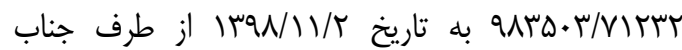
آقاى محمدرضا كاركر، مدير كل محترم موزهها و اموال

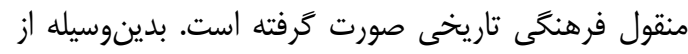
جناب آقاى مهندس محسن موحدى ريبيس سابق

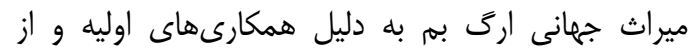
جناب آقاى دكتر محسن قاسمى، رييس فعلى پائياه ميراث

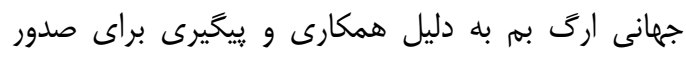
مجوزٍ نمونهبردارى قدردانى مى شودا.

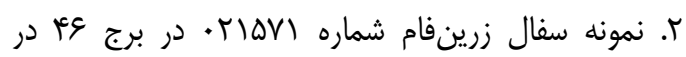

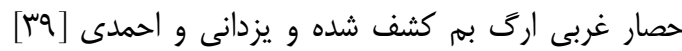

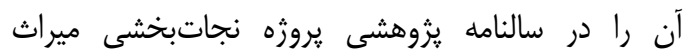

$$
\text { فرهنگى بم ارائه كردهاند. }
$$

\section{References}

[1] Allan J. W. Islamic Pottery. Tr. by Mahnaz Shayestehfar. Tehran: Institute for Islamic Art; 2004. [in Persian].

[آلن جيمز ويلسن. سـفالكرى اسـامى. ترجمـهـ مهنـاز

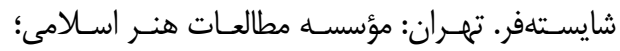

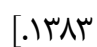

[2] Watson O. Persian Lustre Ware. LondonBoston: Faber and Faber; 1985.

[3] Towhidi F. Pottery Technique and Art. Tehran: SAMT; 2003. [in Persian]. [توحيدى فائق. فن و هنــر سفالكرى. تهـران: سـمت؛

$[.1 \mathrm{l}$ r

[4] Sedighian H, Hajnaseri P. The Lustre Ware during the Middle Islamic Period and its Production Centers in Iran. Islamic Archaeological Studies. 2016; 1: 37-48. [in Persian].

[صديقيان حسين، حاج ناصرى پانتهاً. سفال زريـنفـام

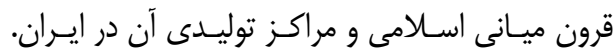

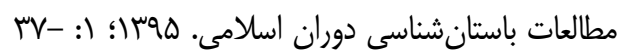

$\left[. \mathrm{IV}^{2}\right.$

[5] Kiyani M, Karimi F. Pottery during the Islamic Period in Iran. Tehran: the Center of Archaeology of Iran; 1985. [in Persian].

$$
\text { [كيانى محمديوسف، كريمى، فاطمـه. هنــر سـفالكَرى }
$$

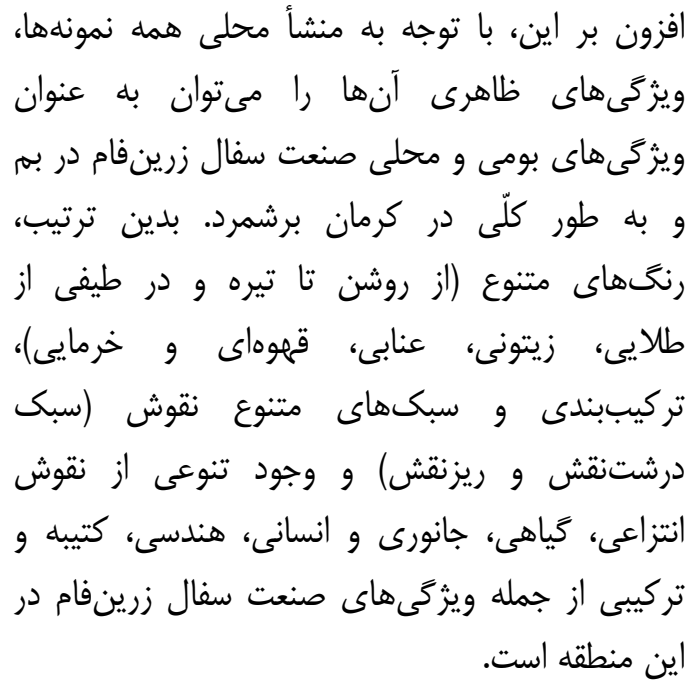

[. - L

[6] Mohsenian M. The Study of Lusterware Ceramics of Iran from 12th - 13th centuries $\mathrm{CE}$ by the Instrumental Analysis methods [unpublished dissertation]. Tehran: Tarbiat Modares Univerity; 2004. [in Persian].

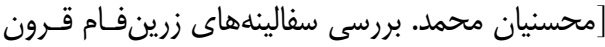

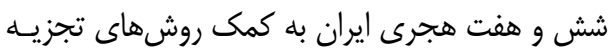

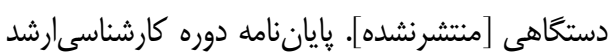

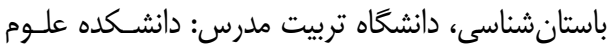

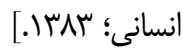

[7] Neyestani J, Roohfar Z. Production of Luster Glaze in Iran; Based on the Historical Studies and Laboratory Research. Tehran: Armanshahr; 2010. [in Persian].

$$
\begin{aligned}
& \text { ]نيستانى جواد، روحفر زهره. ساخت لعاب زريـنفـام در }
\end{aligned}
$$

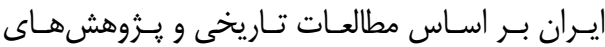

$$
\begin{aligned}
& \text { آزمايشكاهى. تهران: آرمانشهر؛ }
\end{aligned}
$$

[8] Agha-Aligol D, Oliaiy P, Mohsenian M., Lamehi-Rachti M., Shokouhi F. Provenance Study of Ancient Iranian Luster Pottery Using PIXE Multivariate Statistical Analysis. Journal of Cultural 
Heritage, 2009; 10: 487-492. https://doi.org/10.1016/j.culher.2009.01 .003 .

[9] Choubak H. Islamic pottery of ancient city of Jiroft. Journal of Archaeological Studies. 2012; 4(1): 83-112. https://doi.org/10.22059/jarcs.2012.353 77. [in Persian].

] جوبك حميده. سفالينههاى دوران اسلامى شهر كهـن

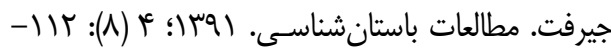

[.人

[10] Amirhajloo S, Emami M, Agha-Aligol D, Riyahian R, Introducing, Classifying and Compositional Study of the Luster Tiles from Kerman. Journal of Research on Archaeometry. 2021; 6(2). [in Persian].

[اميرحاجلو سعيد، امامى محمدامين، آقـاعلى ـــل داوود،

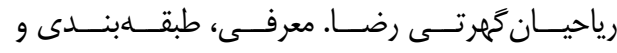
ساختارشناسى كاشىهاى زرينفام يافت شـده از قلعـهـ

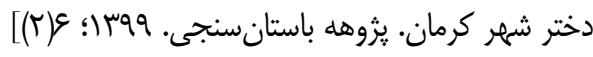

[11] Borgia I, Brunetti B, Giulivi A, et al. Characterisation of decorations on Iranian (10th-13th century) lusterware. Applied Physics A 2004; 79: 257-261. https://doi.org/10.1007/s00339-0042519-z.

[12] Pradell T, Molera J, Smith A D, Tite M S. Early Islamic Lustre from Egypt, Syria and Iran (10th to 13th Century AD). Journal of Archaeological Science 2008; 35: 2649-2662. https://doi.org/10.1016/j.jas.2008.05.01 1.

[13] Ahmadi N, Sajjadi L, Hosseinpour Z, the Research Report of the Studies Center of Bam Archaeological Finds. Vol. 1-5. The Archives of the Bam World Heritage Site; 2010 (Unpublished report) [in Persian].

[احمدى نركس، سجادى هزاوه ليلى، زهره حسين يـور.

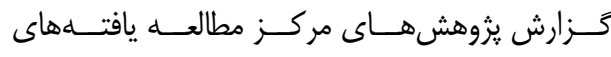

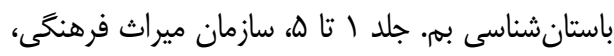

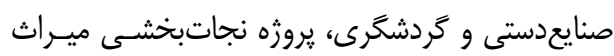

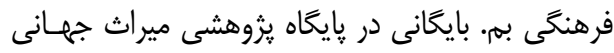

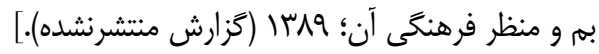

[14] Agha-Aligol D, Mohsenian M, Oliaiy P, Baghizadeh A, Shokouhi F, LamehiRachti M., Movahed B. The Study of the origin of Iranian Lustre Wares using PIXE analysis method. Paper presented at: Physics Conference of Iran 2006. Shahroud University of Technology Central Campus. P. 754-757. [in Persian]. [آقا على باقىزاده على، شكوهى فرح، لامعىرشتى محمد، موحد

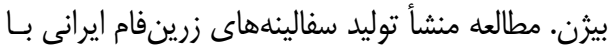

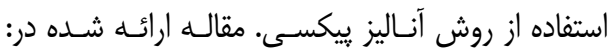

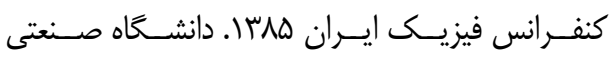
شاهرود؛ ص.

[15] Bahrami M. the complete history of Bam and Arg-e Bam, Publisher: the Author; 2015. [in Persian].

$$
\begin{aligned}
& \text { ]بهرامى مانى. تاريخ جامع بم و ارگ بـهم بـا همكـارى }
\end{aligned}
$$

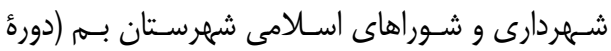

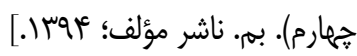

[16] Mehryar M. the Historical Landscape of the Arg-e Bam. Asar. 2004; 36-37: 39-54. [in Persian].

[مهريار محمد. سيماى تاريخى ارگ به. اثر. سربا؛ عس

$$
\text { g }
$$

[17] Soleymani Mo'ez V. The Study and analysis of the motifs of 6th and 7 th centuries Lustre Wares from Reyy. [Unpublished Thesis]. Islamic Azad University Tehran Center Branch; 2010. [in Persian].

[سليمانى معز وحيده. بررسـى و تحليـل نقـوش سـفال

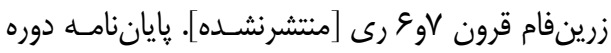

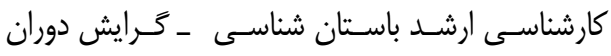

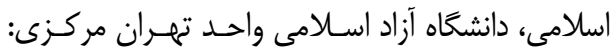

دانشكده ادبيات و علوم انسانى؛

[18] Hosseini S. H, Shirkhani S. An Introduction to the Human Mutifs Typology in the Lustre Wares of the Middle Islamic Ages from Reyy and Kashan. Islamic Art Studies. 2016; 25: 67-82. [in Persian].

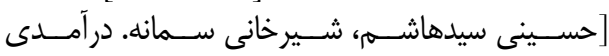

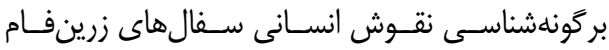

$$
\begin{aligned}
& \text { سدهاى ميانه اسـلامى رى و كاشـان. مطالعـات هنـر }
\end{aligned}
$$

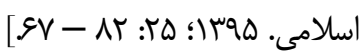

[19] Akbari R. The Study of Lustre Wares collection in the reservoir of Chehelston Museum in Isfahan. [Unpublished Thesis]. Art University of Isfahan; 2012. [in Persian].

[اكبرى راحله. بررسى و مطالعـه مجموعـه سـفالهاى زرينفام مخزن موزه جهبلستون اصفهان [منتشرنشـدهـ. 


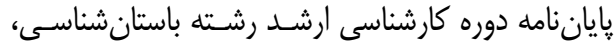

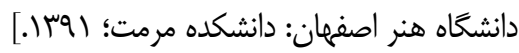

[20] Riyahian R. Sonding for Delimitation of the Qal'eh Ardeshir and Qal'eh Dokhtar in Kerman. The Archives of the Administration of Cultural Heritage, Handicrafts and Tourism of Kerman; 2019 (Unpublished report) [in Persian].

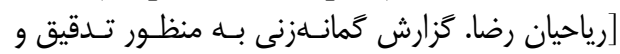

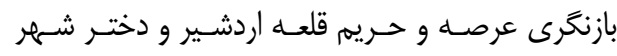
كرمان. بايگانى اداره كل ميراث فرهنگ استى استان كرمان؛

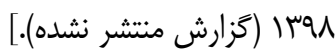

[21] Roohfar Z. A Research on the production of Lustre Glaze in Iran, with emphasis on the treatise of Abolghasem Abdullah Kashani. [Unpublished Dissertation]. Tarbiat Modares University; 2009. [in Persian].

]روحفر زهـــه. يـزوهش در سـاخت لعـاب زرينفــام در

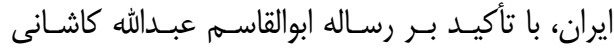
سدهاى V-1 هجرى قمرى [منتشرنشده]. رساله دوره

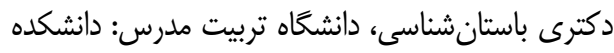

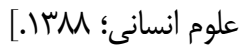

[22] Nasri E. The Study and recognition of Lustre Wares attributed to the sixth, seventh and eighth centuries $\mathrm{AH}$ in Museum of Glass and Pottery of Iran. [Unpublished Thesis]. Art University of Isfahan; 2017. [in Persian].

[نصرى اسماعيل. مطالعه و شناخت سفالينهاى زريـن

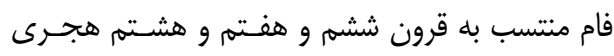

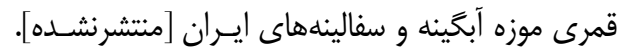

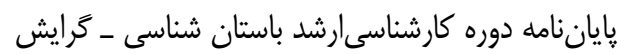

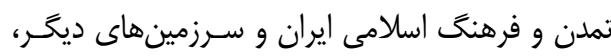

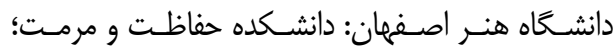

[.1)

[23] Hammati Azandariyani E, Khaksar A, Shabani M. Studying and Analyzing the Islamic Potteries from Underground Troglodytic Architecture Complex at Samen, Malayer. Pazhohesh-ha-ye Bastanshenasi Iran. 2017; 13: 189-206. [in Persian].

همتىازندريانــى اسـماعيل، خاكسـار على، شـعبانى

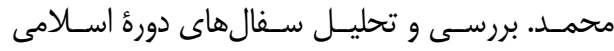

مجموعة معمارى دست كنـــ زيرزمينـى سـامن ملايـر.

يثوهشهاى باستانشناسـى ايـران. عوسا؛ سا:
$[. r+9$

[24] Ra'uf S. Archaeological analysis of the technique of Lustre Wares in the Collection of the Cultural Institution of Museums. [Unpublished Thesis]. Tarbiat Modares University, 2012. [in Persian]. رئوف سولماز. معرفى و تحليل باستانشناختى تكنيك

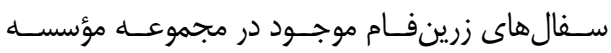

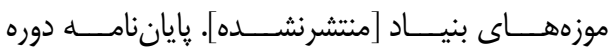
كارشناسىارشد، دانشگاه تربيت مدرس: دانشكده علـوم

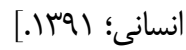

[25] Nikkhah H. Analysis of the Origin of Lustre Wares of Iran (Symbolic Analysis of Motifs) [Unpublished Dissertation]. Tarbiat Modares University; 2014. [in Persian].

] نيكخواه هانيه. واكاوى خاستخاه سفال زرينفام ايـران

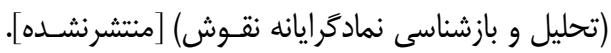

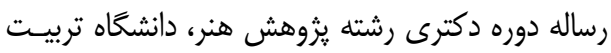
مدرس: دانشكده هنر و معمارى؛ سوس را.]

[26] Priestman S. M. N. A Quantitative Archaeological Analysis of Ceramic Exchange in the Persian Gulf and Western Indian Ocean [Unpublished dissertation]. University of Southampton; 2013.

[27] Grube E. J. Cobalt and Lustre; the First Centuries of Islamic Pottery. In: the Nasser D. Khalili Collection of Islamic Art. London and New York: the Nour Foundation and Oxford University Press; 1994.

[28] Parsaee Borazjani M, Rajabi Cheshani J. Laboratory Studies of Ceramic: Its Background, Capacities, and Perspective in archeology. Paper presented at: the $2^{\text {nd }}$ National Conference on Archaeology of Iran 2015. University of Birjand. P. 1-15. [in Persian].

$$
\begin{aligned}
& \text { [يارسايىبرازجانى مهرداد، رجبى جشانى جواد. مطالعـات }
\end{aligned}
$$

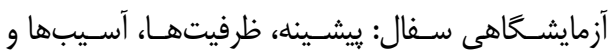

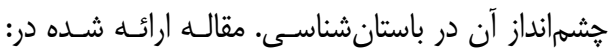

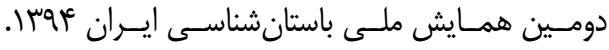

$$
\begin{aligned}
& \text { دانشگاه بيرجند؛ ص. (- ها. }
\end{aligned}
$$

[29] Khademi Nadooshan F, Nayebpour M, Sodaee B. Identification of the Sources of Silver Mining for Parthian Coins in the Province of Medes by PIXE method. Archaeological Studies. 2011; 1: 79-88. [in Persian].

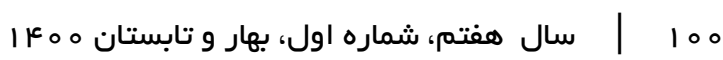


[خادمىندوشن فرهنگَ، نايبيور محمد، سـودايى بيتـا.

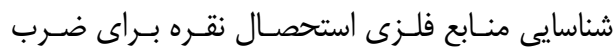

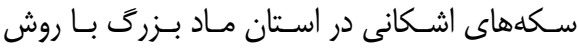

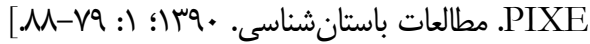

[30] Heydariyan M, Abedi A, Taghizadeh H.

Effective Laboratory Methods in Analyzing Ceramics. Archaeology of Iran 2016; 11: 1-9. [in Persian].

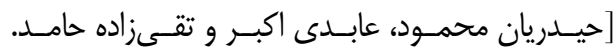

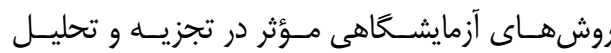

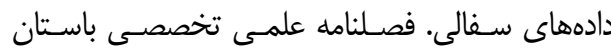

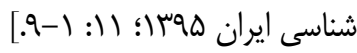

[31] Taghavi A. Origin of Soil Resources Used in Seljuk Ceramics of the ancient city of Jorjan using XRF laboratory method [Unpublished Dissertation]. Tarbiat Modares University; 2010.

تقوى عابد. منشـأيابى منــابع خـاكى مـورد اسـتفاده در

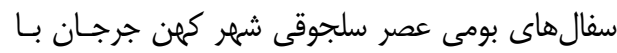

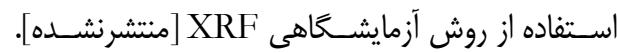

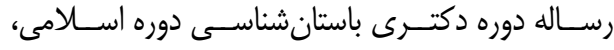

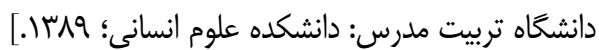

[32] The Geographical Encylopedia of the Villages of Kerman Province - Bam County, Vol. 4. Tehran: Geographical Organization of Armed Forces of Iran; 2003. [in Persian].

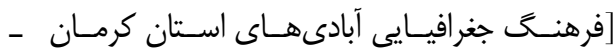

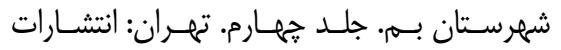

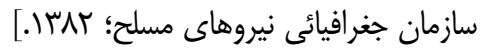

[33] Gonzalez-Garcia F, Romero-Acosta V, Garcia-Ramos G, Gonzalez-Rodriguez M. Firing transformations of mixtures of clays containing illite, kaolinite and calcium carbonate used by ornamental tile industries. Applied Clay Science. 1990; 5: 361-375. https://doi.org/10.1016/01691317(90)90031-J.

[34] Pollard A, Hatcher H. The chemical analysis of oriental ceramic body compositions; part 2: greenwares. Journal of Archaeological Science. 1986; 13: 261-
287. https://doi.org/10.1016/03054403(86)90063-4.

[35] Singh M, Kumar S V. Multi-analytical characterization of XVII century Mughal glaze tiles from northern India. International Journal of Conservation Science. 2017; 8: 389-400.

[36] Montazerzohouri M, Torkiha M, Taheri H. An Archaeological Study on the Provenance and Production of the Lusterware from the Underground Complex of Tappeh Ghaleh, Khomein, Iran Using PIXE. Journal of Archaeological Studies. 2020; 22: 205224.

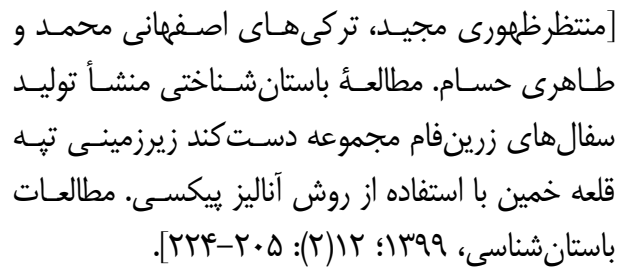

[37] Matin M, Tite M, Watson O. On the origins of tin-opacified ceramic glazes: New evidence from early Islamic Egypt, the Levant, Mesopotamia, Iran, and Central Asia. Journal of Archaeological Science. 2018 1; 97: 42-66.

[38] Tite M. S., Manti P., Shortland A. J. A. Technological Study of Ancient Faience from Egypt. Journal of Archaeological Science. 2007; 34(10): 1568-1583.

[39] Yazdani O, Ahmadi N. The Report of Archaeological Documentation of the Debris Removal Project in The Fortification of Arg-e Bam, Research Annal of the Salvage Project in Bam. 2005; 1: 66-73. [in Persian].

] يزدانى اميد و احمدى نرگس. گزارش مستندنغارى : باستانشناسى از عمليات آواربردارى حصار ارگى بمان.

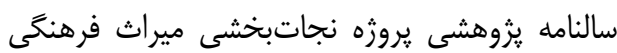

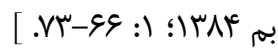

